\title{
Finiteness and children with specific language impairment: an exploratory study*
}

KATRIN LINDNER

Abstract

Children with specific language impairment (SLI) are well known for their difficulties in mastering the inflectional paradigms; in the case of learning German they also have problems with the appropriate verb position, in particular with the verb in second position. This paper explores the possibilities of applying a broader concept of finiteness to data from children with SLI in order to put their deficits, or rather their skills, into a wider perspective. The concept, as developed by Klein (1998, 2000), suggests that finiteness is tied to the assertion that a certain state of affairs is valid with regard to some topic time; that is, finiteness relates the propositional content to the topic component. Its realization involves the interaction of various grammatical devices and, possibly, lexical means like temporal adverbs. Furthermore, in the acquisition of finiteness it has been found that scope particles play a major role in both first-and second-language learning. The purpose of this paper is to analyze to what extent three German-learning children with SLI have mastered these grammatical and lexical means and to pinpoint the phase in the development of finiteness they have reached. The data to be examined are mostly narrative and taken from conversations and experiments. It will be shown that each child chooses a different developmental path to come to grips with the interaction of these devices.

\section{Introduction}

\subsection{Current hypotheses about specific language impairment in children}

One subgroup of children with language-learning difficulties comprises those who suffer from specific language impairment (abbreviated SLI). A five-year-old with SLI, learning German as her first language, can be found to say, 
(1) Ich den Kleber noch raushole.

Target: ich hole (noch) den Kleber (noch) raus.

I the glue still out-get.

'I'll still get the glue out.'

while another four-year-old may express her wishes for her little toy witch by saying,

(2) Hoffentlich heute meine Hexe was Schönes träumen.

Target: hoffentlich träumt heute meine Hexe was Schönes.

hopefully today my witch something nice dream.

'Hopefully my witch will dream something nice today.'

These children use the verb in final position in declarative sentences. Some of them, furthermore, use the bare infinitive. Neither construction is grammatical in German. Rather, in German declarative sentences the finite verb has to be moved into the second position (abbreviated V2) as the target sentences in (1) and (2) indicate. ${ }^{1}$ Typically developing children are able to use the finite verb in V2 by age two to three.

Traditionally, SLI children have been considered as only having a language problem. Thus the group was defined as having a nonverbal IQ within normal range, no apparent hearing problem, no neurological damage or social-emotional disturbances severe enough to be responsible for the language-learning problem. However, for quite some time these four criteria have been subject to dispute. ${ }^{2}$ SLI children with an IQ within normal range have been found to differ from their age peers, but not so much from their language-matched controls in various intellectual tasks like problem solving (Ellis Weismer 1991) or quantificational tasks (Fazio 1990; for a more detailed review cf. Bishop 1992; Johnston 1988, 1994). Regarding their processing skills these children have been shown to differ from their age peers with respect to the perception of brief events (e.g. Tallal 1990) or mental rotation in visual tasks (e.g. Johnston and Ellis Weismer 1983). Furthermore, Johnston and her collaborators found that these children may have greater difficulties in integrating various information simultaneously (e.g. Johnston and Smith 1989; Riddle 1992). These and other studies suggest that children with SLI suffer from a limited capacity for information processing.

In terms of their linguistic skills, current hypotheses hold that children's difficulties are with morphological markers. Thus the "missing agreement hypothesis" (Clahsen 1991) argues that children are not able to establish grammatical relations like agreement on the clausal or the phrasal level. On the clausal level, marking of person and number is impaired, but not tense, since these children are able to produce past participles. In contrast, 
the "optional tense hypothesis" 3 holds that children with SLI use infinitives optionally. It links this optionality to the optionality of tense marking. ${ }^{4}$ While an infinitive is produced when tense is missing, other projections like Comp are said not to be affected.

Both hypotheses have been examined by Hamann et al. (1998) on the basis of data from 50 German SLI children from five different corpora. Yet neither of these hypotheses has been confirmed. The predominant pattern for these children was the finite verb in last position. Moreover, all children had severe problems producing grammatical wh questions and complement clauses. Considering that V2, subordinating conjunctions, and wh pronouns are all hosted in the complementizer phrase (CP), this finding implies that children have difficulties in establishing the link between the "shell formed by the CP" and the propositional core of the clause (cf. Penner 1998). Children with SLI learning German do not achieve the integration of the $\mathrm{CP}$ with the propositional core established by V2. The following questions by five- and four-year-old girls with SLI provide evidence: ${ }^{5}$

(3) Wo der Waschbär hin is? where the racoon gone is?

'Where did the racoon go?

(4) Was ich essen? what I eat INF?

'What shall I eat?'

The wh variable in front is not integrated into the rest of the utterance; see the structure in (5):

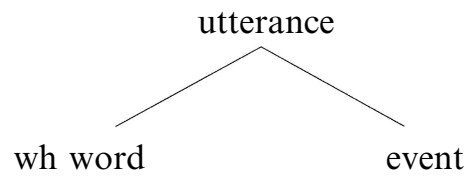

Children's intermediate grammar has the format of a minimal default grammar. It may be considered as an underspecified merger (cf. Chomsky 1995; Roeper 1996; Penner and Roeper 1998) as it instantiates only a subset of the required formal features. This leads to a representation in which the lexical features are projected but (some) categorial and functional features are suppressed. This kind of grammar can be considered to adhere to the minimal default hypothesis, whose basic assumption is the following (cited from Hamann et al. 1998: 203):

All nontarget (intermediate) forms are reflections of a Minimal Default Grammar. The set of defaults is made available by Universal Grammar. All defaults represent 
a more economical form in terms of Economy of derivation or of Economy of representation.

In the following, data from three children will be explored. One of these children shows the pattern just described; that is, she predominantly uses the finite verb in last position (cf. [1] and [3]), while the other two predominantly use the infinitive in last position as documented in (2) and (4). Thus the question is whether these children simply lack syntactic knowledge about the verb position besides morphological finiteness or whether there is more to it.

This paper will consider children's problems within a broader concept of finiteness developed by Klein $(1998,2000)$ and will explore the possibilities this concept offers for the analysis of data from children with SLI. The following section will briefly outline Klein's concept. Sections 1.3 and 1.4 will provide some further background to the analysis, a short summary of information about finite and nonfinite target structures in German, and a brief review of the current research on finite and nonfinite verb forms in first-language acquisition as well as the development of scope particles as an indicator of the development in finiteness. Section 1.5 will outline the questions for the data analysis in section 3, which will follow the description of the participants and the data in section 2. The final section will discuss the findings.

\subsection{Finiteness}

In traditional grammars of Indo-European languages finiteness has been considered to be a property of verbs. In German such suffixes carry information about person, number, tense, and mood, as shown in (6).

(6) a. Ich gehe/du gehst/er geht/wir gehen etc. nach Hause.

'I go/you go/he goes/we go etc. home.'

b. Er ginge nach Hause, wenn er seinen Hausschlüssel bei sich hätte.

'He would go home if only he had his key on him.'

Er ging nach Hause, als er seinen Hausschlüssel fand.

'He went home when he found his key.'

However, as is well known, not all languages provide this information on the verb. Typological studies have considered finiteness not so much a property of the verb (be it a lexical, a modal, a copula, or an auxiliary verb) but rather a property of the clause (cf. Givón 1990; Maas 2001; 
Bisang 2001). Recently Klein (1994, 1998, in particular 2000) has suggested that finiteness establishes a relationship between the utterance's descriptive content and its topic component: finiteness asserts that a state of affairs $\mathrm{p}$ is taken to be true or valid by the speaker for some topic time. Thus Klein (2000: 19) suggests the following structure (with FIN as an abstract operator "finiteness" to be differentiated with regard to the specific tense of a particular utterance):

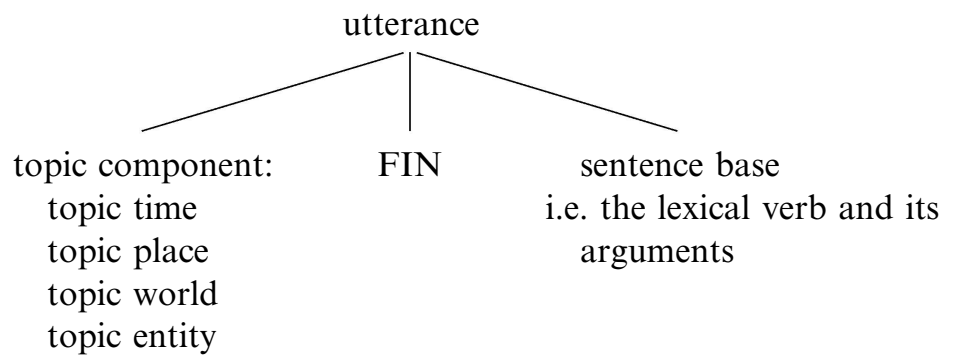

Klein concentrates on utterances with declarative sentences. He finds both syntactic and semantic support for his concept. For this paper the following criteria are relevant:

- FIN has two meaning components (Klein 2000: 15):

a. it carries tense and thus marks topic time, the relevant time for which something is asserted;

b. it marks the assertion of the speaker that a particular state of affairs is valid.

This can best be shown in sentences with contrastive stress (Klein 2000: 13f.). The utterance in (8) can be understood in two ways, (8a) and $(8 b)$ :

(8) $[\ldots]$ he WAS here.

as an answer to a question

a. Is John here?

or

b. Was John not here?

It is the answer in ( $8 \mathrm{~b}$ ) that demonstrates "finiteness." What is being asserted is that John was "here" in contrast to the possibility that he was not "here."

- Only utterances with the finite verb in second position are used with an assertive function so that there is a strong association between the position of finite elements and the assertion. ${ }^{6}$

- In these utterances the argument position of the subject is always 
filled, that is, "there is no grammatical subject without finiteness" (Klein 2000: 7).

- Expletive it is only used with a finite verb. Since this type of construction is closely associated with the topic component this indicates that finiteness has some relationship to the discourse topic.

- Topic time (i.e. the time for which a state of affairs is held to be valid by the speaker) is one of three specifications dealt with in the description of the relationship of time and tense, ${ }^{7}$ the other two being utterance time (or "time of speaking") and situation time (or "event time," in terms of Reichenbach 1947). Topic time is inferred from morphological markers ${ }^{8}$ but it can also be specified by a time adverbial. Note that time adverbials may also be used to specify "situation time" (Klein 1994), that is, the point in time when the event or the situation being talked about obtains. For an illustration take (9) (from Klein 2000: 20).

(9) a. At five, John had left the party.

b. John had left the party at five.

Both sentences involve topic and situation time. In (9a) topic time is set at five, while situation time, the point in time of John's leaving the party, is left unspecified. It is evident from the morphological marking that situation time must precede topic time. In (9b), for example, topic time is in the past but left unspecified, while situation time, John's leaving the party, is set at five.

Klein's concept of finiteness is tied to asserting the validity of a state of affairs $\mathrm{p}$ for some topic time. Thus the language user must intend asserting the validity of $\mathrm{p}$ for a particular time span and have the means to formulate it. Depending on the language its realization in the target grammar involves the use of grammatical devices and, possibly, the use of lexical items. Children learning German, for instance, have to learn (1) that morphological finiteness and the position of the finite verb correlate, (2) that for assertions in the target grammar correlated finite V2 is required, (3) that topic time will be inferred from tense and/or specified by some temporal adverbial, and (4) that there are other more complex interactions between temporal adverbials and tense to express differentiations between topic time, situation time, and utterance time (cf. section 1.4.2).

The following two sections will provide further information about the correlation of finite and nonfinite structures with a particular verb position: section 1.3 gives a survey of these correlations in the target grammar, while section 1.4 reviews briefly the findings of the relevant studies in language acquisition. 


\subsection{Utterances with finite and nonfinite verbs in the target language}

German verb morphology, as in other languages with inflection, distinguishes between the verb stem and affixes: affixes are involved in the formation of nonfinite structures as well as finite structures.

Nonfinite or infinite verb forms include

the infinitive: verb stem $+-e n$

the participle I: verb stem + end

$$
\text { e.g. brauch-en, geb-en }
$$

$$
\text { e.g. brauch-end, geb-end, sei-end }
$$

the participle II: ${ }^{9} \quad(g e+)$ verb stem $+e n /(e) t$.

e.g. ge-géb-en vs. entláuf-en.

or particle $+g e+$ verb stem $+e n /(e) t$.

e.g. dúrch-ge-fahren

Finite verb forms are marked for person, number, tense, and mood; see (6). Regarding verb position, German distinguishes three positions for the finite verb: the first, the second, and the last position (in the following, V1, V2, and VL). See the examples in (10) below, a yes/no question and an imperative sentence in (10a), a declarative and imperative sentence in (10b), and a desiderative and an embedded sentence in (10c):

(10) aa. Hast Du Geld?

'Do you have any money?'

ab. Geh nach Hause!

'Go home!'

ba. Er kommt zum Tee.

'He comes for tea.'

bb. Du kommst heute pünktlich nach Hause.

'You will come home on time today.'

ca. Wenn er doch käme!

'If only he would come.'

cb. ... daß er nicht zur Party kam.

'... that he did not come to the party.'

Infinitives in matrix clauses are allowed in German, yet compared to clauses with finite verbs, there are a number of constraints. Compare the following for adult German (cf. also Fries 1983; Lasser 1997, this issue): with regard to illocutionary acts infinitives can be used in requests (11a), in wishes, (11b), in complaints, (11c), and in rhetorical questions, (11d).

(11) a. Schuhe ausziehen.

'Take your shoes off.' 
b. Einmal nach Amerika fahren.

'To go to America (just/only) once.'

c. Zwei Tage lang Kartoffeln aufklauben!

'Picking potatoes for two days!'

d. Warum nach Amerika gehen?

'Why go to America?'

The verb can be a lexical verb, as in (11), just as well as a modal or copula verb, as in (12) (both examples are taken from Lasser 1997):

(12) a. Immer erster sein.

?'To be always first.'

b. Warum jeden Tag frisches Brot essen wollen?

'Why eat fresh bread every day?'

Syntactically overt subjects are rare (see [13]), yet objects are allowed (cf. [11a], [11c], [12b]):

(13) Ich und Nudeln essen? Nie!

'Me and eating noodles? Never!'

In these cases word order is less flexible than in sentences with a finite verb. A nominative or subject always precedes the object.

If time is marked lexically then not all semantic classes of adverbs are allowed: they mark either a time period (zwei Tage lang) or the repetition of an event (e.g. drei Mal nacheinander); only some deictic adverbs are allowed, like heute 'today', morgen 'tomorrow' but not *gestern 'yesterday'. Thus the event in question is not yet completed (cf. the noncompletedness constraint by Lasser 1997: 64). ${ }^{10}$ See (14a):

(14) a. Zwei Tage lang/Drei Mal nacheinander/Heute/Morgen/

*Gestern wieder Nudeln essen! Wie langweilig!

'Eating noodles for two days/three days in a row/ today/tomorrow/*yesterday again. What a bore!'

b. ... dann die Butter erhitzen. ...

'... then heat the butter. ...'

There are a few types of texts where a topic adverbial dann 'then' may be used with an infinitive, for example in an instruction like a recipe, (14b). This cooccurrence is not acceptable in narratives.

\subsection{Finiteness in first-and second-language acquisition}

1.4.1. Finite verbs in V2 as indicators. German-learning children with normal language development start out with nonfinite verb forms in final 
position; at first infinitives are used and later past participles. By age 2;6 to 3;0 most of them have acquired morphological finiteness correlated with a change in verb position, that is, the finite verb is used in V2. Finite verbs in questions and VL along with a complementizer come in gradually by age three or later. ${ }^{11}$ However, there is still considerable individual variation, with regard to morphological finiteness as well as with regard to verb positions (cf. Fritzenschaft et al. 1990; Kaltenbacher 1990; Tracy 1991, this issue; for a discussion of current hypotheses cf. Weissenborn 1999).

This change in children's intermediate grammars, the distinctions between nonfinite and finite verb forms, and the respective verb positions in matrix clauses have been investigated in greater detail with regard to semantic differentiations: lexical aspect (or Aktionsarten), lexical verb semantics, a temporal or modal interpretation. Jordens (1990) shows that statives and resultatives are used with finite forms in V2 but activity verbs with infinitives or past participles in VL. Wijnen (1997) examines the temporal reference in the interpretation of children's use of eventive and noneventive finite and nonfinite verb forms due to contextual and discourse information. He finds more eventive than noneventive verbs with infinitives. While noneventive infinitives do not indicate future reference, the infinitives with eventive verbs, although mostly interpreted as future-oriented, are essentially free of temporal reference. With finite verbs both verb classes are represented about equally. Here reference to ongoing events prevails. Ingram and Thompson (1996) investigate whether or not children's early infinitives have a modal interpretation, that is, whether they indicate that "some activity will, can or should occur" (Ingram and Thompson 1996: 102). They find infinitives predominantly in modal contexts; finite verb forms prevail in nonmodal contexts. Schaner-Wolles (2000), however, shows that infinitives are not restricted to eventive verbs; even modal verbs may occur in infinitival form and may have a modal or a temporal interpretation, pointing predominantly to the present or future; the few past forms indicate that, generally, the noncompletedness constraint of Lasser (1997) is obeyed. Moreover, based on the observation that these infinitives may be used in V2, SchanerWolles concludes that they may function as a substitute for a tensed form. ${ }^{12}$ Thus the correlation of morphological markers and syntactic position may not be consistent for young normal children at that age. In other words, the distinction of morphological finiteness may be secondary; more important is the syntactic information about V2 (cf. also Schaner-Wolles 1994). Lasser (1997) compares adult use of infinitives to children's use of infinitives. She does not find evidence for a processing hypothesis for children's use of infinitives evaluated on the basis of 
utterance length. On the contrary, she observes that the shorter the utterances the more infinitives are used by both children and adults. Further, while children and adults both employ infinitives mostly with future reference there are certain differences in usage: adults use infinitives to a lesser extent than children; adults prefer the imperative function, while children use more declaratives, mostly desideratives. Lasser (1997: $221 \mathrm{ff}$., this issue) suggests instead that children use the infinitive as a default whenever there are too many demands on the mapping of a particular interpretive feature to a structural form.

1.4.2. Other indicators of finiteness: the use of scope particles. For quite some time the particle of sentence negation - nicht 'not' - has been used as an indicator for the acquisition of V2 (Clahsen 1988; Wode 1977): when nicht occurs to the right of a finite verb in V2 such V2 constructions are assumed to have been mastered; see (15b). Nonmastery is assumed if nicht precedes the verb, as in (15a).

a. (a boy with SLI aged 6;10)

und der Pappa nicht des wissen.

Target: und der Pappa weiss das nicht.

and Daddy not that know INF.

'and Daddy does not know that.'

b. (a girl aged 2;6)

die [Hexe, KL.] beisst mich nicht.

that one [witch] bites me not.

'that one does not bite me.'

In recent studies about untutored first- and second-language acquisition the development of finiteness has been linked to the acquisition of other scope particles. Such particles govern a particular domain within the sentence to which they are either adjacent (preposed or postposed) or nonadjacent.

The particle auch participates in the information structure; its domain may be the focus or, if stressed and in postposition, the (contrastive) topic of the sentence ${ }^{13}$ (Dimroth and Klein 1996; Dimroth, this issue; Nederstigt 2001); compare (16a) with a contrastive topic (stress being indicated by capital letters) vs. (16b) with a focus on salad:

(16) A and B are having lunch together in a restaurant. They are both consulting the menu. They call for the waiter. He comes.

a. A: Ich hätte gerne Spaghetti.

'I would like to have spaghetti.'

B: Ich AUCH.

'me too'. 


\section{b. B: Dazu bitte auch einen SaLAT! \\ 'In addition [to spaghetti] a salad too please'.}

Thus children using auch with stress in postposition as in (16a) appear to have some concept of topic, one of the prerequisites for the application of Klein's notion of finiteness. In first-language acquisition Penner et al. $(1999,2000)$ find auch 'too' earlier than sentence negation with nicht and wh questions. Furthermore, Penner et al. $(1999,2000)$ observe that auch precedes finite V2 (cf. also Nederstigt i.p.; Tracy, this issue). Even when children are able to employ finite V2 they often use auch without a verb or with its nonfinite form (Penner et al. 1999, 2000: 136). Since the scope particle can be in pre- or postposition to the constitutent it is associated with, Penner et al. (1999: 236f.) maintain that this particle acts as a bootstrapping device for children to build up more complex structures, in particular to create a maximal projection above VP.

In a number of cross-linguistic studies about untutored secondlanguage acquisition it has been shown that morphological finiteness is preceded by the stepwise acquisition of auch and other scope particles. Thus Becker and Dietrich (1996) as well as Dimroth (this issue) and Perdue et al. (this issue) outline a developmental path for L2 learners. Dimroth (this issue) investigates auch 'too'/'also' and temporal adverbs noch 'again' and immer noch 'still'. She finds evidence for the following sequence: first the stressed particle is placed right-adjacent to its domain in nonfinite structures, between the topic and the relevant state of affairs, then the particle appears between topic and the finite verb, and finally it is integrated into the VP. Perdue et al. (this issue) observe that L2 learners of French and English start out with aussi/also, too, or seulement/only, then they proceed to temporal adverbs encore/again, and finally to déjà/already. Along with the final group of temporal adverbs learners use the finite verb in second position. One motivation for this development is the wish to express different points in time, for instance to distinguish between topic time and situation time, which are often identified in the developmental stage before; for lack of linguistic means, topic time is either implicitly taken over from the interlocutor or made explicit by an utterance-initial adverb. A temporal adverb like already or German schon allows the relationship between topic time and situation time to be made more precise, namely that topic time is in the post-state of situation time. Thus in a sentence like John has already read the book (taken from Perdue et al., this issue), the finite auxiliary indicates topic time simultaneous with the time of the utterance, while the temporal adverb already indicates situation time with topic time in its post-state. Therefore the use of already allows for a fairly complex expression of time and tense relationships. 
Clearly, children with SLI are not untutored adult L2 learners. However, given the fact that these children have problems with the verb position and morphology it may be interesting to see how they deal with scope particles, in particular given the evidence that all three are related to one another.

\subsection{Leading questions for the analysis of the SLI data}

Children with SLI learning German have difficulties with the positioning of the verb in various sentence types; moreover, some of them have problems with morphological finiteness. Thus children's utterances seem to fail at least one of Klein's essential criteria for finiteness: finite V2. The question is whether they lack other devices as well, like temporal adverbs or other nonfinite forms such as past participles to indicate time and tense distinctions. What developmental stage have these children reached?

This paper will examine which "pieces of the puzzle" are available to three impaired children. Against the backdrop of the development of normal children, in particular the findings by Schaner-Wolles (2000) and Lasser (1997), as well as the findings about scope particles in first- and untutored second-language acquisition the following questions are posed for the analysis of the data from the SLI children:

a. Do children with SLI use scope particles like auch, thereby revealing some knowledge about information structure, in particular about marking topics with a stressed particle in postposition?

b. Do children with SLI make morphological distinctions? Do they differentiate between finite and nonfinite verb forms, between infinitives and past participles, so that there is evidence for tense distinctions?

c. If children with SLI use infinitival forms, do they use them exclusively in VL or do they also use them in V2? Is there evidence that children use the infinitives in V2 as a substitute for a tensed form?

d. (1) Do children with SLI use temporal adverbs? Do they specify topic time? (2) Do they use adverbs like schon, which in L2 development presupposes the use of finite verbs in V2?

These questions will assist in structuring the data analysis in section 3 .

\section{Participants and data}

The German children whose data will be analyzed in this paper form part of a larger group of subjects with SLI studied cross-sectionally in a 
research project in Munich. ${ }^{14}$ All children were seen in their preschools individually about ten times within three to four weeks. The data selected for this study come from children who, at the time of testing, were not undergoing language therapy (however, they had had some in the past). ${ }^{15}$ At the time, only the youngest of the three, child $\mathrm{B}$, had oral motor therapy.

All three children were severely impaired. While their sentencecomprehension skills were well within normal range, their productive skills were two standard deviations below normal range (as measured by the "Logopädische Sprachverständnistest," Parts A and C; Wettstein 1983, abbreviated LSVT). Table 1 presents general information about the three children: their chronological age (given in months) and their nonverbal IQ (measured with the Columbia Mental Maturity Scale, Burgermeister et al. 1972, abbreviated CMMS), as well as test results from the LSVT and from a test of the productive lexicon (measured with the "Aktiver Wortschatztest," Kiese and Kozielsky 1979, abbreviated AWST). All results, except those for production, are at least within normal range. The children's MLU in words was measured on the basis of 250 utterances (with $75 \%$ free play and $25 \%$ narrative data; cf. Johnston 2001). Their MLU ranges from 2.85 to 4.53 in words. Typically developing children with an MLU of 2.85 in the Munich project are about three years old, while an MLU of 3.33 may be observed among three- to fouryear-olds and an MLU of 4.5 in four- to five-year-olds.

Table 2 supplies more information on finite and nonfinite structures in children's conversational data recorded in free-speech situations with pretend play (selling in a toy store, preparing breakfast for dolls and teddies) or in semistructured situations like telling stories to a picture book. ${ }^{16}$ This survey only takes sentences with a subject and a verb into account (cf. one of Klein's criteria in section 1.2). In declarative sentences, all three children predominantly use VL; child A chooses finite verb

Table 1. Nonlinguistic and linguistic skills of the three children $A, B$, and $C$

\begin{tabular}{lllllll}
\hline Child & $\begin{array}{l}\text { Age in } \\
\text { months }\end{array}$ & $\begin{array}{l}\text { Nonverbal } \\
\text { IQ } \\
\text { CMMS }\end{array}$ & $\begin{array}{l}\text { Sentence } \\
\text { comprehen. } \\
\text { LSVT A }\end{array}$ & $\begin{array}{l}\text { Sentence } \\
\text { production } \\
\text { LSVT C }\end{array}$ & $\begin{array}{l}\text { Productive } \\
\text { lexicon } \\
\text { AWST }\end{array}$ & $\begin{array}{l}\text { MLU in } \\
\text { words }\end{array}$ \\
\hline A (girl) & 66 & 116 & PR 98 & PR 2(-2SD) & PR 89 & 3.33 \\
B (girl) & 59 & 114 & PR 98 & PR 2(-2SD) & PR 66 & 2.85 \\
C (boy) & 82 & 123 & PR 90 & PR 2(-2SD) & PR 90 & 4.53 \\
\hline
\end{tabular}

a. The norms for the AWST are valid up to age 6;0. Thus the scores for $\mathrm{C}$ have been evaluated on the basis of boys age $5 ; 0$ to $5 ; 11$. 
Table 2. Infinitives and finite verb forms in the conversational data from the three children $A, B$, and $C$

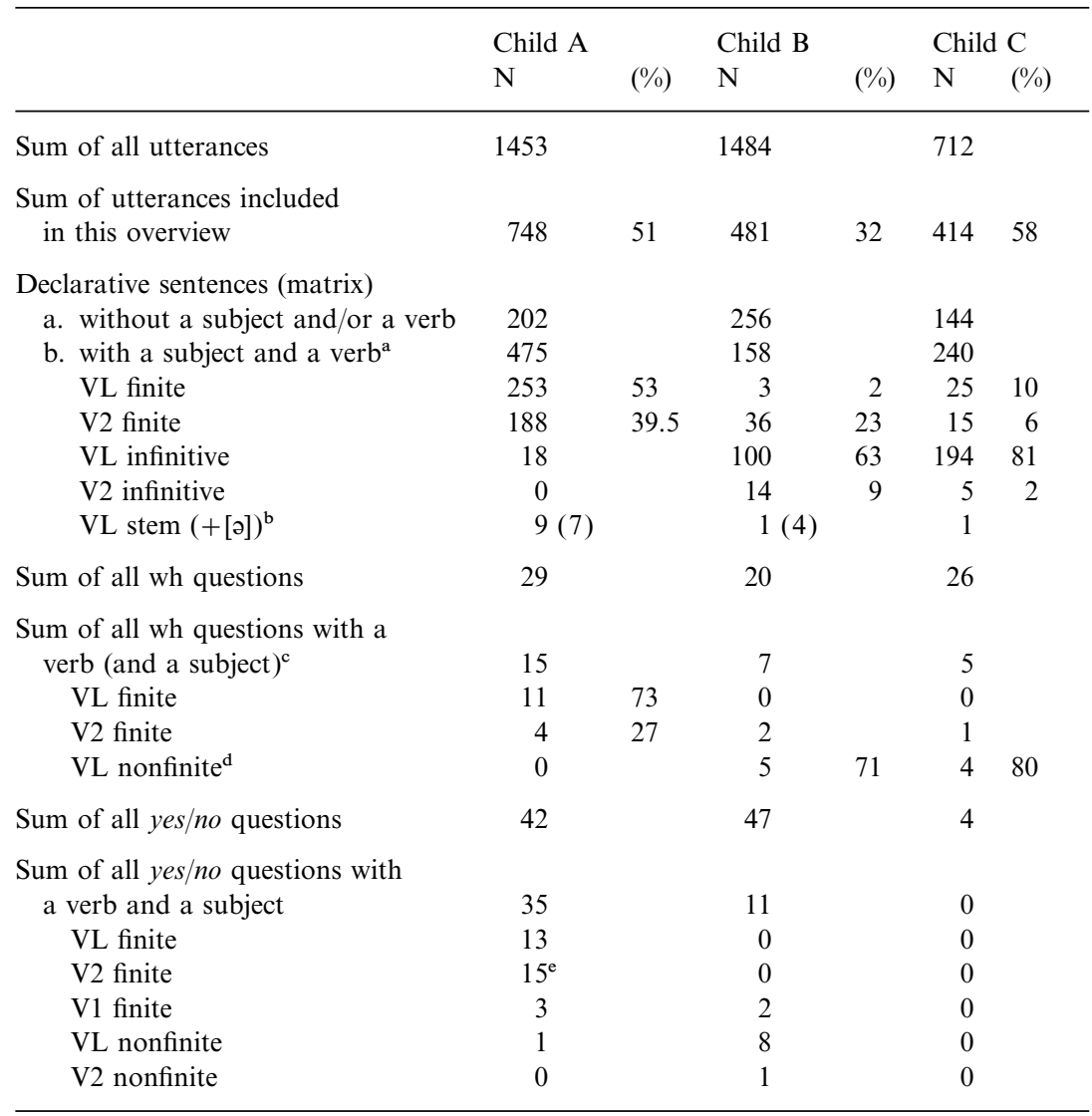

a. Excluded are elliptical sentences, V1-structures with topic drop (17 for A, 3 for B) as well as apokoinou (where two sentences share a common element as the finite auxiliary verb in the following example):

(i) Der is auf M sein Zahnbürst und auf sein Becher aufgeklebt is that one is on $\mathbf{M}$ his toothbrush and on his mug up-glued is. 'That one is glued on M's toothbrush and on his mug.'

b. Verb stem $(+[0])$ : verb stem without a schwa; in brackets: verb stem with a schwa.

c. If not replaced by a wh variable.

d. Nonfinite includes infinitives, verb stems with or without a schwa.

e. A's constructions are of the following kind: subject + finite verb + X; e.g.

(i) Du kennst das (schon)?

'You know that (already)?' 
forms ( $53 \%$ of her verb forms) while child $\mathrm{B}$ and child $\mathrm{C}$ prefer infinitives $(63 \%$ and $81 \%)$. Finite verbs in second position are present in about $40 \%$ of A's declarative sentences, but the percentages decrease to $23 \%$ in the data from $\mathrm{B}$ and to $6 \%$ in the data from $\mathrm{C}$. Yet both $\mathrm{C}$ and $\mathrm{B}$ use a few infinitives in second position (B 9\% and C 2\%). Consequently, A seems to be most advanced with regard to morphological finiteness and verb position; then comes $\mathrm{B}$ with fewer infinitives overall and more infinitives in V2 than C. Further evidence for this distribution of morphological finiteness and verb position comes from children's use of sentence negation with nicht. If this particle follows the verb, this is interpreted as support of V2; if it is positioned to the left of the verb, then this position has not yet been aquired (cf. section 1.4.2). Often the former is associated with a finite verb, the latter with a nonfinite form (cf. also [15a]). This is not the case for all three children: child $\mathrm{B}$, noted for infinitives in V2 in Table 2, also uses nicht right-adjacent to infinitives, for instance particle verbs as in (17). ${ }^{17}$

(17) ich runtergehen nicht.

Target: ich geh nicht runter.

I down-go not.

'I will not go down.'

Again this indicates B's increasing familiarity with V2 even if she does not use adequate morphological packaging. For an overview of the use of nicht for all children, see Table 3 .

Yet all three children have difficulties with wh questions and yes/no questions in the target grammar (cf. Table 2), a characteristic found by Hamann et al. (1998). In wh questions, if there is a verb at all, be it finite or nonfinite, it is used in VL (cf. also [3] and [4] above). Yes/no questions in the target grammar are characterized by the finite verb in first position. However, A still holds onto the two patterns she has mastered; that is, the finite verb is either in last position or in second position. Only three of her questions with V1 are grammatical. Clearly,

Table 3. The use of negation nicht in declarative sentences in the conversational data of the three children $A, B$, and $C$

\begin{tabular}{lccc}
\hline & Child A & Child B & Child C \\
\hline V2 finite + nicht & 14 & 4 & 1 \\
nicht + V2 finite & 9 & 0 & 1 \\
V2 infinitive + nicht & 0 & 10 & 0 \\
nicht + VL infinitive & 0 & 7 & 25 \\
\hline
\end{tabular}


the percentages in Table 2 for V2 (or for VL, respectively) as well as for questions demonstrate that all three children have difficulties with the CP (cf. Hamann et al. 1998).

The data to be analyzed are predominantly narrative, in particular telling stories to pictures since it lends itself best to the task at hand because (1) the shift in topic time may be observed; (2) children's assertions of the validity of a particular state of affairs at some topic time may be examined in relationship to the pictures they talk about.

The data are taken in part from free-speech situations: child A and B tell a story of a picture book to a little cat who loves to listen to stories. Child $\mathrm{C}$ talks about the use of an oven in older times. These data will be contrasted with narrative data from a structured situation, a storytelling experiment with two stories to pictures (following the design of Hickmann 1982). The experiment's procedure was as follows. There were two experimenters with the child, one of them blindfolded in order to prevent her from detecting the secret the child and the other experimenter were sharing. The secret was two sets of pictures (one with five and the second with six pictures), which each made up a story and were dealt with sequentially. The child was asked to sort the pictures into a sequence so "that it would make a good story." Then the child was asked to tell the story to the blindfolded person so that she would be able to tell it back. When the child had finished her story the blindfolded experimenter had a chance to ask questions about the relationships between the events or protagonists in order to find out about the children's understanding of the story. Pretending to be confused the blindfolded experimenter asked the child to tell the story again so that it would be easier for her to tell the story back. Thus there are two versions of each story for each child. The analysis will concentrate on the first version of each story. The data were transcribed in accordance with the conventions of SALT (cf. Miller and Chapman 1984-1991).

\section{Data analysis}

\subsection{Child A}

The first question posed in section 1.5 concerned the use of the scope particle auch. This particle can be used at a distance from its scope or immediately adjacent to it in both pre- and postposition; in the latter case the particle carries stress and has the topic within its scope.

In the conversational data there is evidence that A is able to use auch adjacent to or at a distance from the relevant constituent: in pre-position 
with a focused constituent (cf. [21a]) or in postposition adjacent or nonadjacent yet stressed and therefore indicating that the topic is within its scope (cf. [21b] and [21c], capital letters indicating stress).

(18) a. A has a cold. She explains:

darum ich auch n TUCH umhab.

therefore I also a scarf around-have. 'that is why I am wearing a scarf.'

b. A tells a story. und dann das Mädchen fröhlich is und der Hund AUCH. and then the girl happy is and the dog too. 'and then the girl is happy and the dog too.'

c. Particular toy animals needed some repair in one or the other session. Thus A reminds the experimenter to get the glue too, just in case.

den Kleber brauchen wir $\mathrm{AUCH}^{18}$

the glue need we too.

'we need the glue too.'

Clearly, this child is able to link her sentences to the global topic of a text. Problems arise with the morphological and distributional properties of the verb (questions $\mathrm{b}$ and $\mathrm{c}$ in section 1.5).

According to Table 2 in the conversational data A uses finite verb forms in $92.5 \%$. She marks person and number fairly consistently, ${ }^{19}$ and she differentiates tense, here present tense and present perfect (as will be demonstrated below). However, the majority of her verb forms are in VL (53\%, cf Table 2). ${ }^{20}$ This usage is noted for lexical verbs, auxiliaries like haben 'have' (abbreviated AUX), modal verbs like können 'can' (abbreviated MV), and the copula sein 'be' (abbreviated CV). Of particular diagnostic value are particle verbs (PV) whose discontinuous parts form the sentence brackets in German. Yet children using finite verbs in VL in matrix clauses are unable to realize these brackets. The segment from the conversational data in (19) provides some impression of A's verb usage $(\mathrm{E}=$ experimenter $)$.

(19) Conversational data

A looks through a pile of picture books and chooses one.

A VL AUX

wir das Hexenbücher noch nicht angeschaut haben.

we the witch-books not yet looked-at have.

'we have not yet looked at the witch-books.' 
A chooses a book. She tells the story to a little toy cat. She talks while turning the pages.

\section{A VL PV}

und hier alle runterrodeln.

Target: und hier rodeln alle runter.

'and here everybody down-slides.

'and here everbody slides down.'

E kuck mal hier!

'look here!'

A VL MV

manche hoch und manche runterfahren können.

some up and some down-slide can.

'some can slide up and some can slide down.'

E wie kommt das denn, dass die Hexe da rauffahren kann?

'how come that the witch can go up there?'

A V2 lexical $v$ die hext das mit die Schlitten.

'she practices magic with the sledges.'

A V2 lexical $v$

und hier geht er.

and here goes he.

'and here he goes.'

VL lexical $v$

und dann hier die Baum sich bewegt.

and then here the tree moves itself.

'and then here, the tree moves by itself.'

E mh.

A VL PV

und dann die mit den Baum wegfliegen.

and then those with the tree away-fly.

'and then those fly away with the tree.'

VL CV

dann hier $\mathrm{n}$ grossen Tannenbaum is.

then here a big Christmas tree is.

'then there is a big Christmas tree here.'

$[\ldots]$

A $\mathrm{V} 2 \mathrm{CV}$

da is noch ein Tannenbaum.

'there is still another Christmas tree.'

$[\ldots]$

A describes the witches' living room with the Christmas tree and the gifts 
A V2 lexical v

und hier überhaupt die Geschenke sich bewegen.

Target: und hier bewegen sich die Geschenke überhaupt.

'and here, in any case, the gifts move by themselves.'

$[\ldots]$

A VL lexical $\mathrm{v}$

und dann die eins kriegen.

and then they [the children] one [gift] get.

'and then they get one.'

In her utterances A uses a grammatical subject and the finite verb. Moreover, she locates the various events of the story in a sequence (provided also by the picture book) and shifts topic time: ... and then ... (and) then ... . ${ }^{21}$ Clearly from our perspective of the target grammar, her problem is the finite verb in last position. Thus her sentences are composed of two adjacent parts: the temporal adverbial as part of the topic component and (the rest of) the state of affairs as shown in (20); see also (5). There is not yet any integration of the two, which would come about with the finite verb in second position (cf. Hamann et al. 1998).

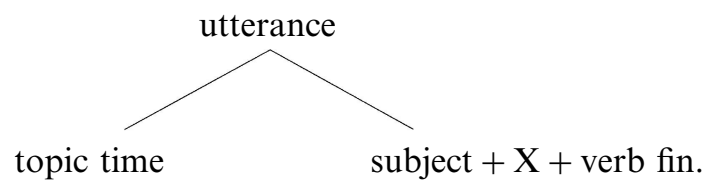

If in a more formal description the topic element were assigned to SpecCP then $\mathrm{C}^{0}$ would not correspond to the finite verb. Thus a "layer CP" may not be assumed. Rather, the structure for most of the child's sentences could be described as in (21), with the topic-time adverb adjoined to IP. ${ }^{22}$ The example is dann die eins kriegen 'then they get one'. 
(21)

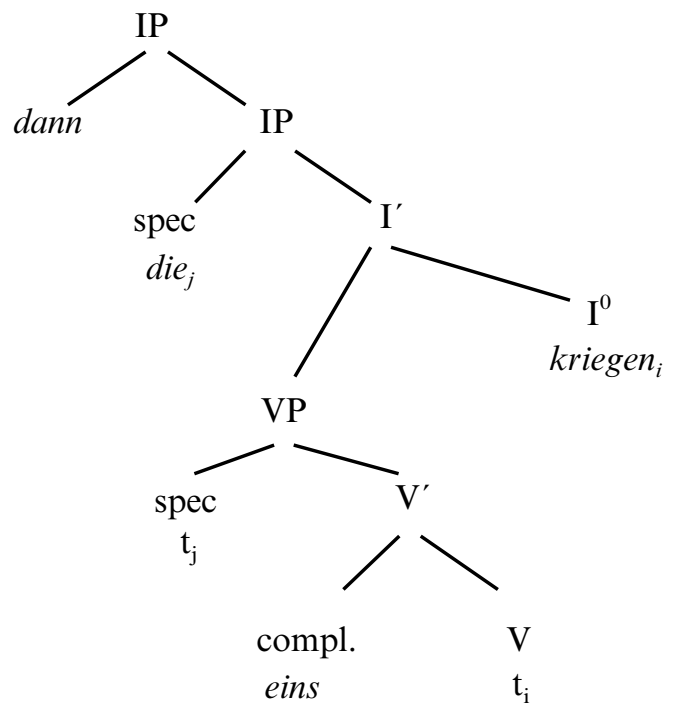

This structure also holds for her utterances in the stories from the experimental data. Table 4 provides an overview of the data in Appendix I.

With the analysis of (19)-(21) we have already progressed to the fourth leading question in section 1.5, the child's use of temporal adverbials. A quite often uses dann to indicate topic time, which again shows that she can handle this part of information structure. The fourth question also addressed the use of the adverb schon 'already'. Recall that Perdue et al. (this issue) found that already/déjà are used by L2 learners with

Table 4. Finite verb forms in A's two stories (experimental data)

\begin{tabular}{|c|c|c|c|c|}
\hline & \multicolumn{2}{|c|}{$\begin{array}{l}\text { Story } 1 \text { (sum of utterances: } 7 \\
\text { verb forms: } 6 \text { ) }\end{array}$} & \multicolumn{2}{|c|}{$\begin{array}{l}\text { Story } 2 \text { (sum of utterances: } 13 \text {; } \\
\text { verb forms: } 14 \text { ) }\end{array}$} \\
\hline & Lexical verb/CV & $\mathrm{PV}^{\mathrm{a}}$ unseparated & Lexical verb/CV & PV unseparated \\
\hline VL finite & 4 & 1 & 7 & 3 \\
\hline $\mathrm{V} 2 / \mathrm{VL}$ finite ${ }^{\mathrm{b}}$ & 0 & 0 & 2 & 1 \\
\hline V3 finite ${ }^{c}$ & 1 & 0 & 0 & 0 \\
\hline V2 finite & 0 & 0 & 0 & 1 \\
\hline $\begin{array}{l}\text { Topic-time } \\
\text { adverb }\end{array}$ & 1 (dann) & & 8 (dann) & \\
\hline
\end{tabular}

a. Particle verb.

b. Ambiguous between V2 and VL (e.g. Hund kommt 'dog comes').

c. The finite verb is in third position. 
the finite verb in V2. This holds also for A. Compare the following example where she uses schon with the present perfect indicating that topic time differs from situation time.
das [Buch] haben wir ja
schon angeguckt.
that [book] have we already at-looked.
'we have looked at that one already.'

Following the analysis by Perdue et al. A is able to distinguish topic time simultaneously with the time of the utterance (indicated by the morphological property of the verb) from the relationship of topic and situation time (indicated by schon) with topic time in the post-state of situation time. Thus she is able to distinguish fairly complex relationships not only by lexical means but also by grammatical means.

A seems to have a number of devices at her disposal but she does not make use of them consistently. As demonstrated by the findings from the conversational and the experimental data, for the most part, she uses finite verb forms in last position. Therefore she still has not yet reached finiteness in the sense of the target grammar. The other two children whose data will be analyzed below show a different pattern.

\subsection{Child B}

Again the analysis starts with a look at the use of scope particles like auch. B uses auch only stressed in postposition; see (23):

(23) a. B has just told the experimenter $\mathrm{E}$ that she likes to look at picturebooks. E responds that she has a whole lot of them.

E: ich hab noch GANZ viele. da kann ich immer wieder I have a whole lot. then I can always bring neue mitbringen.

new [books] along.

B: ich AUCH hier mein Heim (: $)^{23}$ AUCH so viele Bücher. me too here my home (:) too so many books. 'Me too here at home (:) (I have) that many books.'

b. B has just been introduced to a toy witch.

B: ich AUCH so eine Puppe (:) mit Hexenbesen. I also such a doll (:) with a broomstick. 'I also have a doll like this (:) with a broomstick.'

c. $\mathrm{B}$ is seeing the picturebooks for the first time and going through the pile. 
B: so n Buch AUCH hama.

Target: so'n Buch haben wir AUCH.

such a book too have we.

'such a book we have too.'

In the majority of occurrences of auch in B's conversational data the verb is omitted, as demonstrated in (23a) and (23b). In (23c) there is one example of a few where she uses a verb, here haben 'to have' with an enclitic personal pronoun 1st person plural wir 'we'. In all three instances the global topic is the availability of books or toys, and B adds that she too owns such books. Thus the topic of the sentences is within the scope of the particle. In all instances the particle has narrow scope, even in cases like (23c), where in the target grammar the particle would be positioned at some distance from the relevant constituent. However, $\mathrm{B}$ does not yet establish links between constituents across the sentence as was observed with $\mathrm{A}$ in (18c).

Utterances like (23a) and (23b) are reminiscent of utterances of typically developing children observed by Penner et al. (1999, 2000) and untutored L2 learners as described in Dimroth (this issue). AUCH has been considered a precursor of V2 because it opens up a new layer of projections above VP (cf. Penner et al. 1999). Thus B's use of AUCH, in addition to her use of the infinitive in V2, the finite forms in V2, and the position of nicht, as well as the emerging use of particle verbs as sentence brackets, indicates that B is "working" on V2.

Although B does not use auch preposed, she does use other focus particles such as nur 'only' along with a focus accent to show that she is able to mark a focused constituent in the sentence. B, therefore, has some concept of information structure.

The next two aspects to be considered are the morphological and distributional properties of the verb in B's data. Again conversational data from this child will be considered first. According to Table 2, B's use of verbs points to a preponderance of the infinitive in last position (with $63 \%$ ). However, there are also infinitives in second position $(9 \%$, 10/14 in combination with the negation nicht in postposition; cf. Table 3 ). Furthermore $23 \%$ of her finite verbs are in V2. B shows more variation in verb form and position than A. To provide some impression, the following segment demonstrates how her usage varies. Categories are again listed in order to facilitate the analysis: in addition to V2 and VL, V2/VL is used to indicate ambiguity in position; "Inf" stands for infinitive, "Fin" for finite forms and "Inf"/"Fin" for ambiguity in verb form, while the schwa is a substitution of an inflectional suffix by [ə]. ${ }^{24}$ 
(24) Conversational data

B tells the story from a picture book to a little cat.

B a. VL: Inf der Hund (:) der kleine Hund Bett tuen. the $\operatorname{dog}(:)$ the little dog bed do. 'the dog puts the little dog to bed.'

Katze.

cat.

E mhm.

B b. VL: Inf und der Hund ein Auge auflassen. and the dog an eye open-let 'and the dog leaves an eye open.'

c. VL: Inf und dann der Bär streicheln. and then the bear stroke. 'and then the bear strokes (the dog).'

d. VL: schwa und der grosse Hund und die Puppe und der Bär schlaf [ə]. and the big $\operatorname{dog}$ and the dog and the bear sleep.

E mhm.

B e. Repair/V2: Fin der kleine Hund (schleck Wasser) schleckt Wasser \{articulating with great efforts\} 'the little dog (drink water) drinks water.'

f. VL/V2: Inf/Fin

die Puppe und das Hund und der Bär und der grosse Hund schlafen.

'the doll and the dog and the bear and the big dog sleep.'

g. V2: Fin PV

der grosse Hund $\{/\}^{25}$ kleine Hund $\{/\}$ grosse Hund the big dog little $\operatorname{dog}$ big dog schleckt ab.

licks.

'the big dog licks the little dog.'

B h. VL/V2: Fin

der Hund die Puppe und der Bär schlaft. the dog the doll and the bear sleeps. 'the dog, the dolls, and the bear sleep.'

$[\ldots]$

B turns suddenly to E 
B i. VL: schwa ich heute früh schon Zähne putz [ə].

I today early already teeth brush.

'This morning I have already brushed my teeth.'

$\mathrm{E} \quad \mathrm{oh}$ ?

B j. VL: Inf

weil ich hier heute hier mein Zahn bohren.

because I here today my tooth drill.

'because I will get my tooth drilled here today.'

E kriegst du ne neue Plombe?

'will you get a new filling?'

B na.

no.

eine neue Zahn glaub ich.

'a new tooth I think.'

E einen neuen Zahn bekommst du?

'you will get a new tooth?'

B k. VL: Inf

oder des aussen was rauskriegen.

or that outside something out-get.

'or there is something outside that will be taken out'.

B turns back to the book

E was passiert denn da?

'what happens there?'

B 1. V2: Fin + Neg.

(die) der Hund schlaft nicht. ${ }^{26}$ the dog sleeps not.

'the dog does not sleep.'

m. VL + V2: Inf

der Hund aufstehen - rufen eine Katze.

the dog up-get - call the cat

'the dog gets up calls the cat.'

Out of the total of 14 verb forms in VL there are six infinitives: $(24 \mathrm{a})-(24 \mathrm{c}),(24 \mathrm{j}),(24 \mathrm{k})$, and $(24 \mathrm{~m})$; the seventh infinitive is in V2 (rufen in $[24 \mathrm{~m}])$. Moreover, there are two forms with schwa substitution in VL: (24d) and (24i). And there are two forms that are ambiguous with regard to position: (24f) and (24h). Both clauses may be interpreted as VL or as V2. Furthermore, schlafen in (24f) may be interpreted as an infinitive or as the third person plural present tense. In (24h) standard German would choose the plural form (given that all three toys are supposed 'to 
sleep') so there may be an agreement error, but, of course, the child may also list the other toys and may assign the predicate just to the last object. Thus the dominant position for the verb is VL (8/14 plus two ambiguous cases). However, there are also three utterances where the child uses V2 with a finite form: (24e), (24g), and (241). In (24e) with great effort she repairs her first attempt with the verb stem der kleine Hund schleck Wasser and provides the ending $-t$ with schleckt Wasser. In (24g) she uses a particle verb abschlecken and forms the sentence brackets schleckt $a b$; in (241) she even uses the negation particle nicht in the correct postposition: der Hund schlaft nicht. The latter two criteria, bracketing and postposition of the negation nicht, are considered good evidence for V2. In this segment of her conversational data B uses both verb positions, VL and V2. ${ }^{27}$ However, overall in her conversational data the infinitive in VL is dominant.

As for morphological distinctions, B marks person and number in the present tense with the 3 rd person singular, but not with the 2 nd person singular. ${ }^{28}$ Regarding the 1st person singular present tense, most of her verb forms are nonfinite ${ }^{29}$ and only two have a schwa (one of them is [24i]). She also uses the schwa as a substitute for the ending of the 3rd person plural (in [24d], which may also be interpreted as $3 \mathrm{rd}$ person singular or the infinitive). Thus schwa may indicate that the child has some knowledge that this position is reserved for an ending yet no category is assigned to it. ${ }^{30}$ However, these cases are extremely rare. Her plural forms are ambiguous, as demonstrated in (24). Clearly the whole paradigm is not yet established in detail.

For B the infinitive seems to be the default solution to the morphological problem. Like many other impaired children she produces new infinitives that can best be diagnosed with modal verbs (cf. magen in note 27) or with wissen in (25) due to the difference in the verb stem in the singular and plural of the present tense. ${ }^{31}$

(25) ich weissen nimmer was ich noch essen.

Target: ich weiss nimmer, was ich noch essen soll.

I know no longer/not what I still eat.

'I never know what to eat.'

Thus B offers both grammatical and nongrammatical verb forms. If she uses verb endings, they are for the present tense. As for tense distinctions, there are a few past participles, yet they are mostly used without the unstressed prefix ge- and, more importantly, always without auxiliary; compare $(26):^{32}$ 
(26) ich eine Reise wonnen.

Target: ich hab(e) eine Reise gewonnen.

I a trip won.

'I have won a trip.'

B's tense distinctions seem to emerge as evidenced by the use of the few past participles. With regard to morphological and distributional properties of the verb B prefers the infinitive in VL; she still adheres to it when she talks about an event in the past (cf. [27] below).

The fourth leading question was concerned with the use of temporal adverbs. Such adverbs are rare in B's data. A few instances of dann in a spontaneous narrative are provided in (27). In her first utterance she begins with the newly created deictic adverb übergestern (over-yesterday, 'the day before yesterday'). She uses the infinitive to talk about completed events, thus violating Lasser's noncompleteness constraint (cf. section 1.3):

(27) a. R übergestern eine Birne essen.

$\mathrm{R}$ over-yesterday a pear eat.

' $R$ ate a pear the day before yesterday.'

b. und dann ein Zahn wackeln.

and then a tooth loosen.

'and then a tooth was loose.'

c. und dann voll blutet.

Target: und dann hat es voll geblutet.

and then very much bled.

'and then it bled very much.'

d. und dann rausnehmen.

and then out-take.

'and then it was taken out'. [...]

So far the structures produced by B can be described in the following way: for (28) der Hund ein Auge auflassen (cf. [24b]):

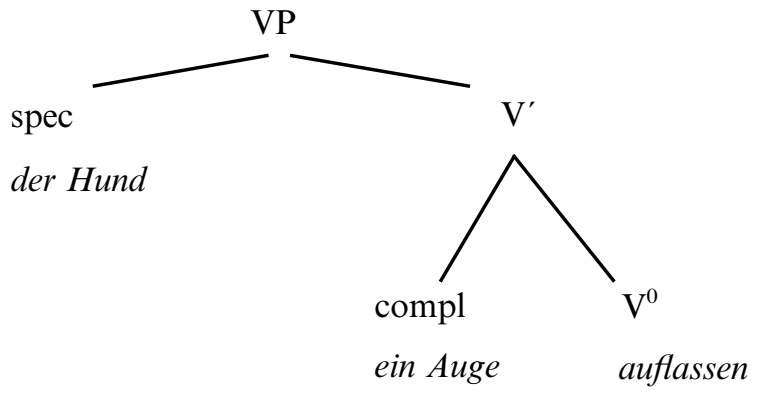


If $\mathrm{B}$ uses a temporal adverbial like dann this is adjoined to the VP. Given utterances with V2 as in (24) and in Table 2 the question arises whether she may also have coexisting more complex structures. ${ }^{33}$ If due to inflection - although the paradigm is not yet complete - a next "layer IP" would be considered appropriate, and such structures could be compatible with those for $\mathrm{A}$ in $(21)$, yet $\mathrm{I}^{0}$ would be left-headed. However, there would be no adjoined adverb since there is no evidence for it in B's data (the closest example could be [29a] but it is a bare verb stem). ${ }^{34}$

No doubt, this child uses finite verb forms in V2. This is documented by the experimental narrative data summarized in Table 5 and provided in Appendix II.

Clearly, B is able to produce the finite verb in the 3rd person singular present tense. On face value the majority of these verbs may be in either second or last position; this is due to the fact that in these sentences a subject is followed only by the verb with elliptical locatives or objects (cf. Appendix II). However, the ambiguity may be resolved in favor of V2; evidence comes not only from utterances with a definite V2 position but also in further experimental data. B responds to the question was is denn jetzt passiert? 'what happened?' with event descriptions like the following: ${ }^{35}$

(29) a. V2, verb stem PV with sentence bracketing dann fahr der Lokomotive rum. 'then drive the locomotive around.'

b. V2 Fin der Bär steht auf ein Stein. 'the bear stands on a block.'

Table 5. Verb forms in B's two stories (experimental data)

\begin{tabular}{lllll}
\hline & $\begin{array}{l}\text { Story 1 (sum of utterances: 6; } \\
\text { verb forms: 5) } \\
\text { Lexical verb }\end{array}$ & PV $^{\text {a unseparated }}$ & $\begin{array}{l}\text { Story 2 (sum of utterances: 6; } \\
\text { verb forms: 8) } \\
\text { Lexical verb }\end{array}$ & PV unseparated \\
\hline V2 finite & 2 & 0 & 0 & 0 \\
V2/VL finite & 3 & 0 & 6 & 0 \\
VL infinitive & 0 & 0 & 0 & 2 \\
Verb stem & 0 & 0 & 0 & 0 \\
$\begin{array}{l}\text { Topic-time } \\
\text { adverb }\end{array}$ & 0 & & 0 & \\
\hline
\end{tabular}

a. Particle verb.

b. Ambiguous between V2 and VL (e.g. Das Pferd rennt 'The horse runs'). 


\section{c. V2 Fin}

der Pinguin sitzt auf den Leiter. etc.

'the penguin sits on the ladder.'

In this experiment $12 / 18$ of her responses contain a finite verb in $\mathrm{V} 2$, two have an infinitive in V2, two more an infinitive in VL; one response is with a verb form with schwa in V2 and one response has a verb stem in V2. Thus, in this experiment, B definitely prefers V2.

Whatever complexity of structure may be ascribed to B's utterances, the most striking fact about her behavior is the difference in grammaticality between constructions in her spontaneous speech and in more structured situations as in the experimental data or when she concentrates on her utterances (as in [24e] and [24g]). In the experimental data infinitives are rare (two in the second story; cf. Table 5). While in the stories her utterances are rather short, in the event description they are longer, running up to six words as in Der Bär steht auf ein Stein (see [29b]). This finding suggests that her use of infinitives depends not on the length of the utterance but, rather, on the type of situation. The less structured the situation is - or the more she is emotionally involved with the content (cf. the embedded sequence in [24] or her narrative in [27]) the more she falls back on infinitives. May these infinitives be considered a substitute for tensed forms as Schaner-Wolles (2000) has suggested for her data? In the conversational data B's infinitives in V2 only run up to $9 \%$. Even if the percentages of finite $\mathrm{V} 2$ are added this only adds up to $32 \%$ compared to more than chance in the data from Schaner-Wolles. On the other hand, the data in Table 5 and in (29) show that B's verb forms are predominantly in $\mathrm{V} 2$ in particular situations. For the moment a more appropriate interpretation seems to be that $\mathrm{B}$ uses the infinitive in VL as a default form. Given that her concentration is limited (cf. [24]), and given that she can produce these forms under "controlled processing," the infinitives are her "easy way out"; they are her most automatized forms (cf. also her new infinitives derived from singular verb stems in [25]). If this interpretation holds, then even the structures with [ə], as in (24) and in some of her experimental data, may be interpreted as symptoms of exhaustion. ${ }^{36}$

In the discussion of (27) it was noted that B uses temporal adverbs to indicate topic time, which brings us back to the section on temporal adverbs. So far it was found that B uses dann 'then' as a topic-time adverb along with the infinitive or the past participle (cf.[27c]) in VL. The other temporal adverb to be considered here is schon. There are a number of tokens in B's conversational data. However, since she does not yet use any auxiliary she is not able to express the present perfect. 
Most of the occurrences of schon are without a verb. ${ }^{37}$ Some of these uses are reminiscent of auch in postposition yet unstressed; see (30).

$$
\begin{aligned}
& \text { Ich schon ein Pony } \\
& \text { I already a pony. } \\
& \text { 'I already have a pony.' }
\end{aligned}
$$

If she uses the temporal adverb along with a verb this is either in the finite present tense form with verbs like haben 'to get to own' (again in the assimilated form of haben wir in hama, cf. [23]) or in the infinitive in VL with wissen 'to get to know'. The adverb is in either case associated with the resultant state of a two-state predicate (cf. Klein 1994 and the attempt in the English translation) with schon indicating situation time, and the finite verb or the infinitive indicating that topic time is simultaneous with the time of the utterance; compare (31) and (32).

(31) B selects stickers. E suggests a bow or a ghost.

B nein. das hama schon.

'no that we have already.'

(32) E suggests a new game to $B$.

B ich schon weissen (:) wie übergestern.

Target: ich weiss schon (so) wie vorgestern.

I already know : like over-yesterday

'I know already like the day before yesterday.'

Verbs like wissen characterize the endstate of a process that started some time in the past but still pertains to the time of the utterance. In that respect this verb implies a period of time up to utterance time; as a consequence more complex relationships are observable, which are no longer exclusively concerned with points in time coinciding with the time of utterance. Yet as was the case with the past participles, contrasting points in time seem to develop at this stage.

B's behavior shows that while her morphological paradigms are not yet complete and tense contrasts are emerging, she is working at the same time on establishing V2 and starts to differentiate topic time from situation time.

In addition to B there is a third child whose behavior is interesting with regard to the issue of finiteness.

\subsection{Child C}

Analysis again begins with the use of the scope particle auch. With A it was found that this particle is used in post- and pre-position, adjacent 
and nonadjacent to its domain. B, however, used it only in postposition. How does $\mathrm{C}$ use auch? Does he make some distinction with regard to topic-focus structures?

Except for one instance of preposed auch with narrow scope (cf. [33a]) all other instances of this particle are postpositioned and stressed and have the topic within their domain; for two further examples see (33b) (taken from C's second narrative in Appendix III).

(33) a. [das is] auch FELL.

'[this is] also fur.'

b. dann [das Pferd] stehn.

then [the horse] stand.

'then the horse stands.'

und die Kuh AUCH stehn da.

and the cow too stand there.

'and the cow stands there too.'

Vogel AUCH.

'bird too.'

Only in the last instance of (33b) is the scope particle used in ways familiar from B and other children, namely as a substitute or precursor for finite V2. In all other instances postpositioned auch is associated with a nonfinite verb. As for other focus particles with a focused constituent, $\mathrm{C}$, like $\mathrm{B}$, quite often uses prepositioned nur 'only'. Thus $\mathrm{C}$ too is able to indicate some information structure.

Regarding the morphological and distributional properties of C's verb forms in Table 2, the verb forms in his conversational data show the following: $81 \%$ of his verb forms consist of the infinitive in VL; the infinitive in V2 runs up to $2 \%$; the finite forms in VL comprise $10 \%$ and in V2 6\%. Even more so than B, this child chooses the infinitive in VL. The following segment of his conversational data will document this usage. Since $\mathrm{C}$ prefers to talk about events he has experienced himself, or about objects he has collected, this segment is about a toy oven that he brought to the session. Again, to facilitate the analysis the categories are listed. Added to those used in the previous sections is "Aux Inf" for an auxiliary in the infinitive and "Past II" for a past participle.

(34) Conversational data

C talks about a toy replica of a little oven and its use in former times, for instance how people used it to cook.
C a. V2: Inf
und Feuer rauskommen dann.
and fire out-come then.
'and fire came out then.'
$[\ldots]$ 
C explains that the ovens had a long pipe (Schlauch) so that they could be moved about in the house.

C b. VL: Inf Aux Inf

duu \{secretively\} früher, früher schon

hey \{secretively\} earlier, earlier already

Zehnmeterschlauch geben haben.

ten-meter-pipe give(n) have.

'hey in former times there existed already a pipe ten meters long.'

E ah ja.

'really.'

E da waren die Wohnungen auch $\mathrm{n}$ bisschen kleiner.

'the apartments were also a bit smaller then.'

$\mathrm{C}$ c. du die ganze Wohnung so klein wie das Zimmer jetzt.

hey the whole apartment as small as this room now. 'hey the whole apartment [was] as small as this room [is] now.'

E ach so.

oh, well.

$\mathrm{C}$ indicates that the oven was as large as the blackboard.

C d. VL: Past II

und das noch alles drin wesen. (pointing to the furniture)

and that still all inside been.

'and all of that was still inside.'

e. VL: Past II Aux Inf

dann noch $n$ Fenster drin wesen haben.

then on top of that a window inside been have.

'then there was also a window inside.'

E ach so.

'indeed.'

C f. VL: Past II Aux Inf

ja solch Ofen teuer wesen haben, solche

yes such ovens expensive been have, such

Rauchofen.

smoke ovens.

'yes such ovens were expensive, such smoke ovens.'

E ja das glaub ich.

'oh I think so.'

C g. VL: Past II Aux Inf

aber die anderen schon billiger wesen haben.

but the others less expensive been have.

'but the others were less expensive.' 
C h. VL: Inf Aux Inf

will zeigen dir wie (früher die :) früher wie die want to show you how (earlier they :) earlier how they wissen haben.

know have.

'(I) want to show you how, in former times, they knew.'

With respect to the distributional and morphological properties of the verb the situation seems to be less complex than with B in section 3.2. Clearly, $\mathrm{C}$ is using the infinitive or the past participle in VL except for a few instances of the infinitive in V2, like the one in (34a) (i.e. $2 \%$ according to Table 2). As with $\mathrm{B}$, his preference for the infinitive is also documented by new infinitives derived from the verb stem of the present tense singular; compare (35).

(35) mein Papa nich weissen.

Target: mein Pappa weiss (es) nicht.

my Dad not know INF.

'my Dad does not know (it).'

The number of past participles is limited. Most of them are wesen (target: gewesen 'been') from the verb sein 'to be' (cf. [34d]-[34g]). Due to the omission of the unstressed prefix ge-, other constructions may be ambiguous, like (34b), where geben may be interpreted as the infinitive or as the past participle (without prefix). Yet taking (34h) into account the decision may be in favor of the infinitive again. It is noteworthy that $\mathrm{C}$ not only regularizes infinitives (as in [35]), but he also generalizes the auxiliary haben for all instances of auxiliaries in the present perfect, in contrast to the two distinct auxiliaries haben and sein in the target language. Nevertheless, despite this limitation to a few forms, $\mathrm{C}$ is able to indicate that some events happened in the past. Thus his usage does not violate the noncompleteness constraint of Lasser (1997) although, of course, his forms are not found in the target grammar.

According to Table $2 \mathrm{C}$ also uses a few finite verb forms, most of them being copula or modal verbs; see (36) (as well as his second story in Appendix III).
a. das s leicht. ${ }^{38}$ 'that' s easy.'
b. ich darf da so was anreden.
I am allowed there to announce something.
'I am allowed to announce something there.' 
c. zwei [Aufkleber] krieg ich.

two [stickers] get I.

'I'll have two.'

d. du brauchs keine $\mathrm{xx} \cdot{ }^{39}$

'you don't need any xx.'

C's usage of verb forms in the experimental data shows much more variation; compare the survey in Table 6 of the data presented in Appendix III.

Although the infinitives in VL still prevail there is now also one infinitive in V2 and one in V1. In addition, C now uses verb stems in various positions as well as two finite verbs in V2 (again a modal verb and a copula; cf. Appendix III, story 2). C's use of verb forms is largely bound to infinitives in VL. The possibility that his infinitives might be a default form for finite forms in V2 - following Schaner-Wolles (2000) may be excluded due to the low percentages of infinitives in this position.

Table 6. Verb forms in C's two stories (experimental data)

\begin{tabular}{|c|c|c|c|c|}
\hline & \multicolumn{2}{|c|}{$\begin{array}{l}\text { Story } 1 \text { (sum of utterances: } 11 \text {; } \\
\text { verb forms: } 8 \text { ) }\end{array}$} & \multicolumn{2}{|c|}{$\begin{array}{l}\text { Story } 2 \text { (sum of utterances: } 11 \text {; } \\
\text { verb forms: } 15 \text { ) }\end{array}$} \\
\hline & $\begin{array}{l}\text { Lexical } \\
\text { verb/CV/MV }\end{array}$ & $\begin{array}{l}\mathrm{PV}^{\mathrm{a}} \\
\text { unseparated }\end{array}$ & $\begin{array}{l}\text { Lexical } \\
\text { verb/CV/MV }\end{array}$ & $\begin{array}{l}\text { PV } \\
\text { unseparated }\end{array}$ \\
\hline V2 infinitive & 0 & 0 & 1 & 0 \\
\hline $\mathrm{V} 2 / \mathrm{VL}$ infinitive ${ }^{\mathrm{b}}$ & 1 & 0 & 0 & 0 \\
\hline VL infinitive & 2 & $1^{\mathrm{d}}$ & $8^{\mathrm{e}}$ & 1 \\
\hline V1 infinitive & 0 & 0 & 0 & 1 \\
\hline V3 infinitive $e^{c}$ & 1 & 0 & 0 & 0 \\
\hline V2 verb stem & 0 & 1 & 0 & 0 \\
\hline $\mathrm{V} 2 / \mathrm{VL}$ verb stem $^{\mathrm{b}}$ & 1 & 0 & 0 & 0 \\
\hline VL verb stem & 0 & 0 & 1 & 0 \\
\hline $\begin{array}{l}\text { Verb stem } \\
\text { (self-repair) }\end{array}$ & 0 & $1^{\mathrm{d}}$ & 0 & 0 \\
\hline VL finite & 0 & 0 & 0 & 1 \\
\hline V2 finite & 0 & 0 & 2 & 0 \\
\hline Verb omission & 3 & 0 & 0 & 0 \\
\hline Topic-time adverb & $\begin{array}{l}1(\text { dann }) \\
2(\text { jetzt })\end{array}$ & & 3 (dann) & \\
\hline
\end{tabular}

a. Particle verb.

b. Ambiguous between V2 and VL due to two constituents.

c. The verb form is in third position.

d. This verb has been created by $\mathrm{C}$ as a particle verb (stress on the particle).

e. One of these infinitives forms part of an apokoinou: Da des is die Katz kommen with Katze as the constituent shared by both sentences. 
With regard the use of temporal adverbs, the fourth leading question in section 1.5, a few are found in C's data. In (34) the whole story about the oven is situated "in former times" (früher); see (34b). Moreover, in his two stories in the experimental data there is reference shift und dann .../jetzt 'and then .../now' following the sequence of events.

A description of C's clauses in the data presented here would start with a VP with the infinitive or even the infinitive/past participle + auxiliary haben base generated in $\mathrm{V}^{0}$. The adverbial früher is adjoined again to the highest projection of VP. Thus C's clauses seem to convey the following structure: for früher Zehnmeterschlauch geben haben see (37). ${ }^{40}$

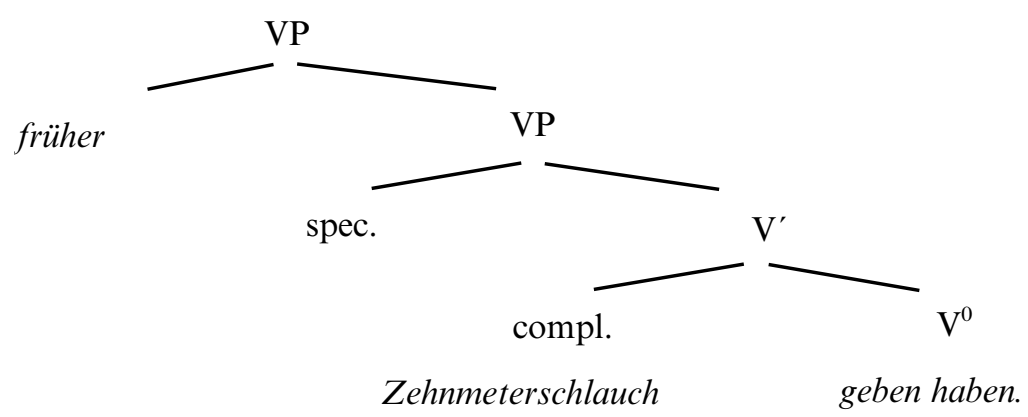

Thus, like B, C uses the time adverb adjoined, along with nonfinite verb forms in VL.

As for schon, the temporal adverb that was observed to correlate with finite verbs, there is hardly any evidence for schon with a temporal reading in C's data. Most of the occurrences are focus particles, like the instance in (34b). However, there are two examples in which C, like B, uses the particle with the verbs wissen or kennen; see (38).

a. mein Pappa schon wissen, welches Los wir haben. my Daddy already know which lottery ticket we have. 'my Daddy already knows which lottery ticket we have.'

b. aber die Füchse ich schon kennen. but the foxes I already know 'but the foxes I know already.'

Although the temporal reading of schon seems to be available the particle is not yet correlated with finite verbs (cf. Perdue et al., this issue). However, as was shown with $\mathrm{B}$, there seem to be first attempts to dissociate topic time, situation time, and time of utterance. C, like B (cf. [32]) uses the temporal adverb with two-state predicates where situation time lies before topic time, which is simultaneous with utterance time. 
The third child also uses infinitives predominantly in VL. In contrast to child $\mathrm{B}$, he is even more rigid in regularizations. Yet at the same time he is capable of differentiating "tense" distinctions with these limited devices and he seems to start to differentiate points in time by means of adverbs. Nevertheless, similar to B, this child too shows more flexibility in his verb forms and verb positions when he speaks in more structured situations. It is important to note that, overall, his syntax is fairly complex; for instance he uses embedded sentences, as in (34h) and (38a). Thus these structures are elaborate - except for the distributional and morphological properties of the verb. It almost looks as if $\mathrm{C}$ keeps that part of his sentences constant in the conversational data while a more structured situation seems to provide more support for him to explore other verb forms.

\section{Discussion}

Children with SLI have been known for their difficulties with verb morphology in inflectional languages, and those who learn German have problems with the syntactic properties of the verb as well, in particular with the second or first position. In this paper a concept of finiteness has been explored that is broader than the usual concept of morphological finiteness employed in research about children with SLI so far. This concept has been developed by Klein $(1998,2000)$. In his view, finiteness is tied to the assertion that a certain state of affairs is valid with regard to some topic time. Thus it involves the correlation and the interaction of syntactic, morphological, semantic/pragmatic, and lexical devices. Since these are acquired gradually as studies on L1 and L2 learners show, the paper investigates at which stage three children with SLI are with regard to their development of "finiteness."

Four leading questions were posed to assist in structuring the analysis of the data. The first question was concerned with the use of scope particles to mark topic and focused elements. The second and third questions dealt with the morphological and distributional properties of verbs to examine emerging tense contrasts and the correlation of the finite verb form and verb position. The last question was concerned with the use of temporal adverbs that express topic time or differentiate more complex structures, as in the interaction of schon 'already' with tense distinguishing utterance time, situation time, and topic time.

None of the three children has yet mastered semantic "finiteness" in the target sense. All the children are able to provide some information structure; that is, they mark topic elements and focused elements by 
means of scope particles, in particular through the use of auch. Thus one of the prerequisite building blocks for finiteness has been acquired. However, with regard to verb position, morphological finiteness, and the use of temporal adverbs each child seems to choose a slightly different "route."

Child A relies on morphological finiteness. She differentiates tense morphosyntactically. However, with regard to verb position, the minority of her finite verb forms are in V2, the relevant position for assertions in the target grammar. She uses temporal adverbs to mark reference shift in topic time, but most of the time expressions are adjoined to the left. Yet she is already able to use the adverb schon with finite V2, which allows her to differentiate between situation and topic time (simultaneous with the time of utterance). She is, without a doubt, the most advanced of the three children, having acquired a number of devices necessary to express finiteness but, most of the time, she does not yet link the topic component with the rest of the sentence via V2. This holds both for her conversational data and for the experimental data. Thus her performance does not depend on the type of situation. This is not the case with the other two children.

Child B employs a number of constructions dependent on the kind of speech situation. In free speech she prefers the infinitive with VL, while in semistructured situations (telling a story from a picturebook to a toy cat) and even more so in experimental situations she predominantly marks the third person singular present tense and uses it in V2, sometimes making great effort to do so. Tense distinctions seem to emerge (cf. her use of participles without auxiliary). She indicates a shift in topic time with adverbials like dann 'then', but, overwhelmingly, in combination with nonfinite verb forms in VL (cf. also the past participle without a subject in [27c] and a verb stem in [29a]). Yet she too makes use of the time adverb schon. She may use it without any verb in second position, that position that has been reserved for postposed particles like stressed auch (cf. [30]). Or if she uses a verb it is a two-state predicate like wissen '(to get) to know', allowing her to indicate that topic time is in the poststate of situation time.

Child C, again, shows a different "route." He seems to have the concept of tense and produces tense contrasts when locating events in the present or in the past, but he does not use agreement. He predominantly chooses infinitives in VL. This holds for the conversational data but less for the experimental data, where he shows a variety of verb forms, finite verbs and verb stems, in various positions. With regard to temporal adverbs, he is able to mark a shift in topic time, yet due to VL he does not link the two components; like B he uses schon, with two-state predicates. 
$\mathrm{B}$ and $\mathrm{C}$ are comparable in their use of time adverbials; in short, they prefer them with nonfinite forms. ${ }^{41}$ Such combinations are also employed when talking about the past, yet only B violates Lasser's noncompletedness constraint for infinitives (cf. [27]).

The data from these three children with SLI, in particular the nonfinite structures from $\mathrm{B}$ and $\mathrm{C}$, provide a slightly different picture than that reported on normal younger children earlier (cf. section 1.4). In contrast to findings by Jordens (1990), the two impaired children show no sensitivity toward correlations of Aktionsarten with verb form and verb position. Yet, in accordance with the findings by Schaner-Wolles (2000), they use not only lexical verbs in the infinitive but also modal verbs. Furthermore, child $\mathrm{C}$ regularizes auxiliaries as well, a phenomenon that has not been previously observed among typically developing children. ${ }^{42}$ As for temporal reference, the infinitives are not restricted to present or future events; child B may also refer to past events. Finally, combinations of temporal adverbials with root infinitives have not been found in narrative data from normally developing children so far. ${ }^{43}$ Thus there are a number of distinctions in the use of matrix infinitives between normally developing younger children and two of these children with SLI.

Although all three children clearly use constructions (including the protracted use of finite verbs in VL with child A) that are not observed among younger typically developing children learning German, there is no indication that they have difficulties with the concept of asserting the validity of a state of affairs $\mathrm{p}$ at some topic time. Lasser (1997: 84) has pointed out that while morphological finiteness implies that $p$ is asserted, the absence of morphological finiteness does not necessarily imply the absence of the assertion or that the assertion of $p$ is not intended. ${ }^{44}$ No evidence has been advanced so far that would call this methodological point of view into question. Furthermore, these children appear to have a number of conceptual "pieces to the puzzle" and some of their linguistic realizations at hand, such as markers for information structure or temporal adverbials. These "building blocks" have been found to characterize the developmental stage preceding finiteness in L1 and untutored L2 learners (e.g. Dimroth, this issue; Dimroth and Jordens 2001).

Finiteness in the target grammar presupposes linking of grammatical and/or lexical devices via finite V2. As was noted before none of the three children has reached this stage yet. With regard to the grammatical devices, each of them seems to break up the task into different parts, keeping some of them fairly stable. Child A keeps the finite verb in last position; $\mathrm{C}$ does the same, but on top he stabilizes verb morphology; 
while child $\mathrm{B}$ resorts to the infinitive in VL, in particular in free-speech situations. Thus for A the "default" still seems to be finite VL; for B and $\mathrm{C}$ the "default" is the infinitive in VL in the conversational data. ${ }^{45}$ Consequently these children use or even create minimal default forms, finite VL or nonfinite VL. Clearly the major problem is V2, so that the difficulties are associated with the verb position; that is, the topic component is not yet integrated with the rest of the sentence.

These observations about the linguistic behavior of the three children support the "minimal default hypothesis"; in particular they show that these children have difficulties with the CP (cf. Hamann et al. 1998, 2001). Yet this represents a rather simplified picture that does not do justice to the full range of their skills. CP hosts a complex system. Since it mediates between the propositional content of the sentence and the discourse into which it is embedded, the system comprises force (e.g. marked with wh elements in wh questions), topic element(s), and the focus of the sentence in case of a topicalized NP with contrastive stress (cf. also Rizzi 1997; Hamann et al. 2001). The question is how this complex system is gradually built up. For instance, either force in the utterances of children can be inferred from the context or it is made explicit in contradictions (nein! 'no!') or by intonation (e.g. with a rise even in the case of ungrammatical questions); topic and focus are marked by particles like auch. Apparently some of the components of $\mathrm{CP}$ are present at a rather early stage in typically developing children (cf. section 1.4). This holds also true for the data from the three children with SLI in this study. These early "building blocks" need more attention and certainly need to be taken more seriously in future research on SLI children. In particular "layers" below CP and above IP, or possibly VP, like a topic phrase or a focus phrase (cf. Penner et al. 1999: 237) have to be examined in greater detail. Thus the description of the data for A, $\mathrm{B}$, and C in (21), (28), and (37) is not satisfying, since it does not give credit to the children for producing topic elements (even though they are adjoined).

The lack of integration via finite V2 is observed in the data of this study to differing degrees. Child A predominantly has a syntactic problem, while $\mathrm{C}$, in addition, has difficulties with inflection. Yet he is able to provide some morphological and syntactic variation in structured situations. This is even more the case with child B. Lasser (1997) did not find any evidence for processing limitations with regard to sentence length. The data from $\mathrm{B}$ and $\mathrm{C}$ show that for them it is the situation type that matters; that is, the more structured the situation, the more grammatical the sentences of the two children $\mathrm{B}$ and $\mathrm{C}$ become. In freespeech situations the children's morphosyntactic skills are not yet so 
automatized as to allow for the grammatical expression of states of affairs in which they are emotionally involved.

Such findings call to mind the studies about capacity limitations in the literature, such as the experiments by Johnston and Smith (1989). The two authors investigated children's strategies in comparing objects with regard to size, color, and identity. Their subjects with SLI differed from their normal peers in one particular strategy, which combined a dimensional analysis with quantitative groupings (as in pick two green ones). The impaired children were successful if they could employ one or the other strategy. The authors concluded that in the case of the combined strategy these children were operating near the limits of their processing resources. ${ }^{46}$ Thus there seem to be similar phenomena in different domains. It is worthwhile to look into these phenomena from linguistic and nonlinguistic domains in more detail and to examine the possibilities for a more comprehensive theory about specific language impairment. For these children, clearly, linking the topic elements to the "rest of the sentence" via V2 is a task too demanding at this point in their language development. Yet some necessary "ingredients" for semantic finiteness are already available.

Klein's notion of semantic finiteness allows for a far more comprehensive view of children's language development and linguistic skills than morphological concepts of finiteness. This holds not only for L1 and untutored L2 learners but also for children with SLI. This concept, along with the findings about precursors of finiteness, allows us to pinpoint what these children have already achieved and what they are still "working on"; a number of structures, possibly competing and of differing degrees of complexity, can be detected (cf. in particular the data from B). Furthermore, this concept allows us to pinpoint in greater detail what these children still have to learn and what their learning difficulties may be. Dimroth and Jordens (2001) report that untutored L2 learners of Dutch may stop short before they arrive at the final stage of finiteness. Having acquired a few "building blocks" (like the scope particles) and thereby being able to convey what they want to say, they may lose the motivation to reach the target form. Stagnation in the learning process is often observed among children with SLI. Thus this approach may also open up new perspectives for studying their language-learning problems. 


\section{Appendix I. Experimental data from A: telling a story to pictures ${ }^{47}$}

The first story

A no V

hier das Pferd $>$

here the horse $>$

VL

und hier Anlauf nimmt.

and here running starts

'and here (it) starts running.'

VL

hier das Pferd steht.

'here the horse stands still.'

VL PV

des Pferd hier rüberspringt.

the horse here over-jumps

'here the horse jumps (over the fence).'

V3

hier verwundet is (:) das Pferd.

here hurt is (:) the horse

'here the horse is hurt.'

VL

und hier eine Kuh kommt.

and here a cow comes

'and here comes a cow.'

VL

un dann die Kuh das Pferd derbindet.

and then the cow the horse dresses

'and then the cow dresses the horse ('s leg).'

\section{The second story}

A VL

hier ein Nest ist.

here a nest is

'here is a nest.'

VL

da drei kleine Vögel sind und ein Muttervogel.

there three little birds are and a mother bird

'there are the three little birds and a mother bird.'

VL PV

dann die Muttervogel wegfliegt.

then the mother bird away-flies

'then the mother bird flies away.'

VL 
dann die allein sind die Kinder.

then they alone are the children

'then they are alone, the children.'

V2 PV

dann hochklettert (:) die Katze.

then up-climbs (:) the cat

'then the cat climbs up.'

$\mathrm{V} 2 / \mathrm{VL}$

Hund kommt.

dog arrives

'the dog arrives.'

V2/VL PV

und dann hochgeht.

and then up-goes

'and then (he) jumps up.'

VL

und dann die Mutter kommt.

'and then the mother comes.'

VL PV

und der Hund anfässt.

and the dog on-holds

'and the dog gets hold (of her).'

VL PV

dann der Hund die Katze an Schwanz festhalt.

then the dog the cat on tail on-hold

'then the dog holds on to the cat's tail.'

VL

und daaaann (:) die Mutter füttert.

and theeeen (:) the mother feeds

'and then (:) the mother feeds (her children).'

$\mathrm{V} 2 / \mathrm{VL}$

Hund kommt.

dog comes

'the dog comes.'

VL, VL

und dann die Katze so sitzt und den Hund überhaupt nich seht.

and then the cat so sits and the dog not at all sees

'and then the cat sits like that and does not see the dog at all.'

\section{Appendix II. Experimental data from child B: telling a story to pictures}

\section{First story}

B das Pferd rennt.

'the horse runs.' 
das Pferd kuckt zu die Kuh.

'the horse looks toward the cow.'

das Pferd rennt da.

'the horse runs there.'

das Pferd schlaft.

'the horse sleeps.'

das Pferd steht.

'the horse stands still.'

no $\mathrm{V}$

das Pferd Bein ein Aua.

the horse leg an ouch

'the horse's leg has an "ouch.",

The second story

B des Vogel steht.

'the bird stands.'

des Vogel fliegt.

'the bird flies.'

die Katze schaut.

'the cat looks.'

VL: Inf PV

die Katze hochklettern.

the cat up-climb

'the cat climbs up.'

VL: Inf PV

der Katze die Katze runterfallen.

the cat the cat down-fall

'the cat falls down.'

der Vogel fliegt [repair] steht. — der Vogel steht.

'the bird flies stands - the bird stands.'

\section{Appendix III. Experimental data from child C: telling a story to pictures}

\section{First story}

C VL: Inf PV

und jetzt des Pferd erst so hochtrapperen.

and now the horse first so up-gallop

'and now the horse first gallops up.'

wissen wie?

Target: weisst du wie (ich das meine)?

know INF how

'do you know what I mean?' 
verb stem PV

hochtrap.

E was macht das Pferd?

'what is the horse doing?'

C V2: verb stem PV

des des hochspring immer so.

that that up-jump always so

'that always jumps up like that.'

V2/VL: Inf

und dann stehn.

and then stand

'and then it stands still.'

V3 Inf

und die Kuh auch stehn da.

and the cow too stand there

'and the cow stands there too.'

no V/AUCH

Vogel auch.

'(the) bird too.'

V2/VL: verb stem

und das Pferd spriiing.

and the horse spriing

'and the horse jumps.'

no $\mathrm{V}$

des Pferd da des da Zaun putt.

the horse there that fence broken

'the horse tore the fence.'

no $\mathrm{V} /$ particle

də Vogel wieder her.

the bird again here

'the bird has come back again.'

VL Inf

und jetzt (des Pferd die Kuh) den Vogel den Krankenkoffer holn.

and now (the horse the cow) the bird the sick chest get.

'and now [...] the bird gets the medicine chest.'

VL Inf

und des Kuh des Pferd Bein dabindn.

and the cow the horse leg dress

'and the cow dresses the horse's leg.'

\section{The second story}

C V2: Fin MV

$\mathrm{x}$ will auf sein Nest mit seine Kinder.

$\mathrm{x}$ wants on his nest with his children 
' $\mathrm{x}$ wants to be in her nest where her chicks are.'

V2: Fin CV; VL: Inf

da des is die Katze kommen.

there that is the cat come

'there is the cat, the cat comes.'

V1: Inf PV

hochkuckn auf den Baum.

up-look on to the tree

'she looks up at the tree'.

VL: Fin PV; V2: Inf

wenn der Vogel wegfliegt da holen sie.

when the bird away-flies, then get them

'when the bird flies off, then she will get them.'

VL: Inf

und dann die Katze noch starren.

and then the cat still stare

'and then the cat stares up (?).'

VL: Inf

und dann der Hund kommn,

VL: Inf; VL: Inf

sehn (:) auf den Baum steigen.

and then the dog come see (:) on the tree climb

'and then the dog comes and sees her climbing up the tree'.

VL: Inf; VL: Inf

der Hund kommn an den Schwanzi die Katze an Schwanz ziehen.

the dog come on the tail the cat on tail pull

'the dog comes and pulls at the cat's tail.'

VL: Inf PV

und dann der Vogel wieder reinkommen.

and then the bird again into-come

'and then the bird returns (to the nest).'

VL: verb stem

und der Hund die Katze jag.

and the dog the cat chase

'and the dog chases the cat.'

VL: Inf

und die Piepsen schön Futter kriegen.

and the birdies nice food get

'and the little birds get nice food.'

\section{Notes}

* The data analyzed in this study were collected in the research project "Funktionale Determinanten im Spracherwerb" funded by the Deutsche Forschungsgemeinschaft 
(DFG, Akz. CA 50/6-1 and SE 249/4-2). I would like to thank my colleagues Christina Schelletter, Kerstin Täubner-Benicke, and Sabine Stoll. For very helpful comments on earlier versions of this paper I am grateful to Ellen Brandner, Cornelia Hamann, Stephen Laker, Patrizia Noel, Clive Perdue, Rosemarie Tracy, Ingeborg Lasser, Christine Dimroth, and two anonymous reviewers. Correspondence address: Institut für Deutsche Philologie, Universität München, Schellingstr. 3, D-80799 München, Germany. E-mail: katrin.lindner@germanistik.uni-muenchen.de.

1. Declarative sentences with topic drop will not be considered here; e.g.

(i) (Das) weiss ich schon. that know I already

'That I know already.'

2. In Germany the ICD-10 - the International Classification of Diseases (1991) edited by the World Health Organisation, roughly equivalent to the Diagnostic and Statistical Manual of Mental Disorders IV (1994) edited by the American Psychiatric Association - includes learning-disabled children with SLI as well (i.e. children with an IQ down to 70). With regard to neurological damage the findings are not clear-cut yet. It is well known, however, that there is some biological basis; e.g. Bishop et al. (1995), Tomblin and Buckwalter (1996).

3. This hypothesis, originally called the "optional infinitive" hypothesis, was introduced by Rice et al. (1995) as the "extended optional infinitive" into the research on SLI. For an examination of German SLI data see Rice et al. (1997).

4. Wexler (1994: 338) states "that the child does not distinguish values of T. If values of T are not distinguished, then there is no semantic role for $\mathrm{T}$ to play at LF." Thus Schönenberger et al. (1996: 52) suggest, "For a child in the OI stage tense is optional."

5. Such nonintegrated structures are also found in children with normal development; e.g. Fritzenschaft et al. (1990), Tracy (1994), and the literature cited there.

6. This assertive function is suspended in wh questions, which, in German, also have finite V2: Wer kommt zum Essen? 'Who comes for dinner?' The assertive function is not excluded automatically for subordinate sentences; however, this has to be discussed e.g. in relation to the complementizer.

7. The notion of topic, and thus topic time, can best be characterized when seen as given in a text question (cf. von Stutterheim 1997). Such a text question for a narrative could be, for instance, "What happened to $\mathrm{x}$ at time $\mathrm{t}_{\mathrm{i}}$ ?" In the answer to such a text question, i.e. in the text, topic time is in "topic position"; for instance, "At $t_{i} x$ did $y$, then/at $t_{i+1}$ $\mathrm{x} \operatorname{did} \mathrm{z} \ldots .$.

8. The preferred example is the pluperfect: cf. Mary returned and John had already prepared dinner. So they sat down and enjoyed it. Topic time is some $t_{i}$ before the time of the utterance $\mathrm{t}_{0}$, while John's preparing dinner (situation time) was at some time before topic time.

9. The choice of prefix and suffix depends upon morphological (strong vs. weak verbs), syntactic (separable verbs vs. nonseparable verbs), and phonological information (position of the word accent).

10. Other deictic adverbs like bald 'soon' or frequency adverbs like häufig 'frequently' are only acceptable if used with an overt subject as in Ich und bald heiraten. Unsinn! 'Me and getting married soon. Nonsense!'

11. In our corpus in Munich there is a normal child who uses embedded sentences introduced by dass 'that' by age 2;8. Cf. the following: Mein Mama hat gesagt, dass ich einn Hase krieg in Januar 'My mama has said that I get a rabbit in January'. 
12. In the longitudinal data of her subject Schaner-Wolles finds that the child uses $91 \%$ of his infinitives in V1/V2 from age 2;2-2;5. This percentage decreases to $55 \%$ from age $2 ; 5-2 ; 8$.

13. "Contrastive topic," as Dimroth (this issue) notes, makes sense only when considered on a more global level of discourse organization. In (16) 'we' as a global topic (with constrastive ' $I$ ' and 'I') is established via the previous actions like going together to a restaurant, selecting a dish, and calling for the waiter.

14. The participants were 23 children with SLI, aged 4-6, and 60 children with normal development, aged 2-6. All subjects spoke the Munich city dialect. The majority came from middle-class families. Data collection included various experiments and freespeech samples.

15. Unfortunately there were no records about their therapies in the past.

16. Telling a story to a picture book is called a semistructured situation since children are not completely free in their actions due to the story line of the books.

17. This example is particularly interesting, since such particle verbs are of diagnostic value for V2 as well, cf. section 3.1.

18. A topicalizes a few adverbials, some demonstrative pronouns as accusative objects, e.g. im Gras is der (in the grass is that one) 'that one is on the grass', den hab ich ja schon (that one have I already) 'that one I have already', and very few full NPs.

19. Besides the instances mentioned in Table 2 (18 infinitives and 16 verb stems with or without schwa) there are only nine instances with wrong number marking and six with wrong person marking.

20. For a child with a similar behavior see Kaltenbacher and Lindner (1991).

21. Other adverbs to indicate topic time are e.g. morgen 'tomorrow'. For instance, when talking about what $\mathrm{E}$ and $\mathrm{A}$ will do the next morning,

(i) $\mathrm{V} 2$
A morgen mag die [Hexe] Bilder und die weiss das. tomorrow wants that one [the witch] pictures and that one knows it. 'tomorrow that one wants pictures and (that one) knows it.'

To indicate topic place A uses a number of locatives; cf. (19).

22. A more interesting alternative would be a topic phrase (TopP) above IP (cf. Tracy, this issue).

23. (:) indicates a pause of less than a second.

24. The schwa is an ending for the 1st person singular present tense, as in ich gehe 'I go', and for several subjunctive forms, which, however, are not expected to be used by these children.

25. $\{/\}$ signifies a rise in intonation.

26. In Bavaria the umlaut is often not realized. Thus it is acceptable to say schlaft 'sleeps' instead of schläft.

27. This variation can also be observed in her wh questions and yes/no questions:

(i) VL infinitive

aber welches grünes Brot die Hexe meinen?

but which green bread the witch mean

'but which green bread does the witch mean?'

(ii) V2 finite

was tut denn hier die Ente?

what does then here the duck

'what does the duck do here?' 
(iii) V2 infinitive

Katze du magen Nutella?

cat you like Nutella

'cat do you like Nutella?'

28. Her 2nd pers.sg. is not marked at all: it is either the verb stem or the infinitive; or the verb is omitted altogether.

29. Of the 100 infinitives in Table 2, 46 are used with the first person singular.

30. There are also four instances of schwa for the $3 \mathrm{rd}$ person singular along with topic drop (cf. Table 2).

31. Cf. Ich weiss, du weisst, er weiss, wir wissen, etc. Both wissen and the modal verbs like mögen in note 27 belong to a group of verbs that have kept the strong past tense forms as present tense forms and formed new weak past forms. The change in the stem vowel in the present tense thus goes back to a change in stem vowel that is still characteristic for strong verbs in past tense.

32. The only exceptions are in her responses in another experiment where she uses weggeräumet 'away-put' (target weggeräumt). The omission of the unstressed prefix is quite common among typically developing children at a younger age. In the München corpus we have a few two-year-olds who do so consistently.

33. Note that the verb form auflassen in (28) need not be an argument against a more complex structure, in which der Hund could be in spec IP (Rosemarie Tracy, personal communication).

34. An even further layer, $\mathrm{CP}$, is not relevant at this stage of development given that there is no further evidence such as a topicalized NP. (24g) could be the only, yet not convincing, example; cf. her two starts. Furthermore, her wh questions seem to be just emerging; cf. Table 2 and note 27.

35. In (29a) and (29c), B produces gender errors (die Lokomotive and die Leiter are feminine and not masculine); in (29b) and (29c) there are case errors. The preposition auf 'on' governs the dative. Again these are utterances that she produces with effort. For more details cf. Lindner (n.d.).

36. Such forms can also be observed with normally developing children in similar situations when they are tired (Ellen Brandner, personal communication).

37. Most of the occurrences are tokens of schon wieder $X$ 'again', schon fertig 'all ready', and the like; in many cases the interpretation between a temporal reading and a reading as a focus particle is not quite clear.

38. All copula forms are of the 3rd person singular. Most of them are present tense. Yet there is one form with the past tense war 'was' and one auxiliary form, in Die Hose auch teuer wesen war 'These trousers had been expensive, indeed'.

39. $\mathrm{xx}=$ incomprehensible.

40. The expletive it in the target sentence would be generated in the IP.

41. This may point to a preference for lexical means over grammatical devices (here morphological finiteness), which Moore and Johnston (1993) found among children with SLI learning English. The scores of their five-year-old participants with SLI were comparable to those of the three-year-old controls in terms of grammatical skills and comparable to the four-year-old normals with regard to their use of adverbials.

42. Modal interpretations of root infinitives have not been investigated in any great detail; but it might be noted that both $\mathrm{B}$ and $\mathrm{C}$ are able to add the modal verb if necessary. This may be some indication that modal interpretations will only play a marginal role.

43. Cf. also section 1.3. One reason is, of course, that morphological finiteness seems to be acquired by 2;6 while time adverbials seem to emerge between age 2;6 and 3 (at least in the data from the two-year-olds in the Munich corpus). On the other hand, the majority 


\section{$844 \quad$ K. Lindner}

of subjects mentioned in section 1.4.1 are younger than 2;6. A shift in topic time indicated by dann 'then' in cooccurrence with past participles is documented for Swiss German children with SLI in Hamann et al. (1998: 226f.).

44. It should be rather difficult to prove that these children do not have the intention or the concept of asserting the validity of some state of affairs $p$. The methodological situation is similar to that of studying word semantics: if children use a particular expression, do they have the particular concept or the particular entry or not? Without special experiments, one has to resort to evaluating children's use of the words. Thus, with regard to assertions one may want to look for repairs, for contrastive usage, for protests - or examine children's telling of stories to pictures to study how related their descriptions are to the depicted event, a solution chosen in this study. However, whether or not these children are conscious of the validity of some state of affairs is another story. This would have to be examined in line with children's concept of lying or "telling the truth," which, following Wimmer et al. (1984), four-year-olds of typical development seem to have.

45. A comparison of L2 learners to children with SLI is fairly difficult at the moment, since a number of characteristics, like VL for SLI children, have also been found for L2 learners (C. Perdue, personal communcation). Yet, no doubt, this is an important task for the future.

46. The analysis of Johnston and Smith (1989) showed, for instance, that inferences about size demand more processing resources than those about color, since judgments about size are inherently ordinal but those about color are not.

47. Legend used in Appendices:

(:) pause

$>$ incomplete utterance

The experimenter's acknowledgments have been omitted.

\section{References}

Becker, Angelika; and Dietrich, Rainer (1996). The acquisition of scope in L2 German. Zeitschrift für Literaturwissenschaft und Linguistik 104, 115-140.

Bisang, Walter (2001). Finite vs. non finite languages. In Language Typology and Language Universals, Martin Haspelmath et al. (eds.), 1400-1413. Handbücher zur Sprache und Kommunikationswissenschaft 20.2. Berlin: Mouton de Gruyter.

Bishop, Dorothy V. M. (1992). The underlying nature of specific language impairment. Journal of Child Psychology and Psychiatry and Allied Disciplines 33, 3-66.

-; North, T.; and Donlan, C. (1995). Genetic basis of specific language impairment: evidence from a twin study. Developmental Medicine and Child Neurology 37, 56-71.

Burgermeister, Bessie; Blum, Lucille H.; and Lorge, Irving (1972). Columbia Mental Maturity Scale. New York: Harcourt Brace Janovich.

Clahsen, Harald (1988). Critical phases of grammatical development. A study in the acquisition of negation in children and adults. In Language Development, Peter Jordens et al. (eds.), 123-148. Foris: Dordrecht.

- (1991). Child Language and Developmental Dysphasia. Amsterdam: Benjamins.

Chomsky, Noam (1995). The Minimalist Program. Cambridge, MA: MIT Press.

Dimroth, Christine; and Jordens, Peter (2001). Finiteness in first and second language acquisition of Dutch. Paper presented at the conference "Acquisition of verb grammar 
and verb arguments," Zentrum für Allgemeine Sprachwissenschaft, Typologie und Universalienforschung, Berlin.

-; and Klein, Wolfgang (1996). Fokuspartikeln in Lernervarietäten. Ein Analyserahmen und einige Beispiele. Zeitschrift für Literaturwissenschaft und Linguistik 104, 73-114.

Ellis Weismer, Susan (1991). Hypothesis testing abilities of language impaired children. Journal of Speech and Hearing Research 34, 1329-1338.

Fazio, Barb (1990). Cognitive and linguistic factors associated with young languageimpaired children's counting abilities. Unpublished doctoral dissertation, Indiana University.

Fries, Norbert (1983). Syntaktische und semantische Studien zum frei verwendeten Infinitiv und zu verwandten Erscheinungen im Deutschen. Tübingen: Narr.

Fritzenschaft, Agnes; Gawlitzek-Maiwald, Ira; Tracy, Rosemarie; and Winkler, Susanne (1990). Wege zur komplexen Syntax. Zeitschrift für Sprachwissenschaft 9, 52-134.

Givón, Talmy (1990). Syntax. A Functional Typological Introduction, vol. 2. Amsterdam: Benjamins.

Håkansson, Gisela (1998). Language impairment and the realization of finiteness. In Proceedings of the 22nd Annual Boston University Conference on Language Development, vol. 1, Annabel Greenhill et al. (eds.), 314-324. Somerville, MA: Cascadilla.

Hamann, Cornelia; Lindner, Katrin; and Penner, Zvi (2001).Tense, reference time and language impairment in German children. In Auditiatur Vox Sapientiae, Caroline Fery et al. (eds), 182-213. Berlin: Akademie Verlag.

—; Penner, Zvi; and Lindner, Katrin (1998). German impaired grammar: the clause structure revisited. Language Acquisition 7(2-4), 193-245.

Hickmann, Maya (1982). The development of narrative skills: pragmatic and metapragmatic aspects of discourse cohesion. Unpublished doctoral dissertation, University of Chicago.

Ingram, David; and Thompson, William (1996). Early syntactic acquisition in German: evidence for the modal hypothesis. Language 72, 97-120.

Jordens, Peter (1990). The acquisition of verb placement in Dutch and German. Linguistics 28, 1407-1448.

Johnston, Judith R. (1988). Specific language disorders in the child. In Handbook of Speech Language Pathology and Audiology, Norman J. Lass et al. (eds.), 685-715. Toronto, Ontario: Decker.

-(1994). Cognitive abilities of children with language impairment. In Specific Language Impairments in Children, Ruth Watkins et al. (eds.), 107-122. Baltimore: Paul Brookes.

- (2001). An alternate MLU calculation: magnitude and variability of effects. Journal of Speech, Language and Hearing Research 44, 156-164.

-; and Ellis Weismer, Susan (1983). Mental rotation abilities in language disordered children. Journal of Speech and Hearing Research 26, 397-403.

-; and Smith, Linda (1989). Dimensional thinking in language impaired children. Journal of Speech and Hearing Research 32, 33-38.

Kaltenbacher, Erika (1990). Strategien zum frühkindlichen Syntaxerwerb. Tübingen: Narr.

-; and Lindner, Katrin (1991). Some aspects of delayed and deviant development in German children with specific language impairment. In The Proceedings of the Conference on Child Language Disorders, Per Egil Mjaavatn et al. (eds.), 216-231. Report 24. Trondheim: Norsk Senter for Barneforskning.

Kiese, Christiane; and Kozielski, Peter-M. (1979). Aktiver Wortschatztest für drei- bis sechsjährige Kinder. Weinheim: Beltz.

Klein, Wolfgang (1994). Time in Language. London: Routledge. 
- (1998). Assertion and finiteness. In Issues in the Theory of Language Acquisition. Essays in the Honour of Jürgen Weissenborn, Norbert Dittmar et al. (eds.), 225-245. Bern: Peter Lang.

- (2000). On finiteness. Unpublished manuscript, Max Planck Institute for Psycholinguistics, Nijmegen.

Lasser, Inge (1997). Finiteness in adult and child German. Unpublished doctoral dissertation, City University of New York. (Available through Max Planck Institute for Psycholinguistics, Nijmegen, or through the author.)

Lindner, Katrin (n.d.). Normale und gestörte Sprachentwicklung bei Kindern. Studien zum Verstehen und zur Produktion.

Maas, Utz (2001). "Finite" and "nonfinite" from a typological perspective. Unpublished manuscript.

Miller, Jon; and Chapman, Robin (1984-1991). Systematic Analysis of Language Transcripts. Madison: Waisman Center, University of Wisconsin.

Moore, Mary-Evelyn; and Johnston, Judith R. (1993). Expressions of past time by normal children and language-impaired children. Applied Psycholinguistics 14, 515-534.

Nederstigt, Ulrike (2001). The acquisition of additive "focus particles" in German. In Proceedings from the 25th Annual Boston University Conference on Language Development, Anne H. L. Do et al. (eds.), 554-565. Somerville, MA: Cascadilla.

-(i.p.). Additive particles and scope marking in spoken child German. In Semantics Meets Acquisition, Veerle van Geenhoven (ed.). Dordrecht: Kluwer.

Penner, Zvi (1998). Learning theoretical perspectives on language disorders in childhood developmental dysphasia in Swiss German. Fachgruppe Sprachwissenschaft der Universität Konstanz Arbeitspapier 89, 110-187.

-; and Roeper, Tom (1998). Trigger theory and the acquisition of complement idioms. In Issues in the Theory of Language Acquisition. Essays in the Honour of Jürgen Weissenborn, Norbert Dittmar et al. (eds.), 77-112. Bern: P. Lang.

—; Tracy, Rosemarie; and Weissenborn, Jürgen (2000). Where scrambling begins: triggering object scrambling at the early stage in German and Bernese Swiss German. In The Acquisition of Scrambling and Cliticization, S. M. Powers et al. (eds.), 127-164. Dordrecht: Kluwer.

-; Tracy, Rosemarie; and Wymann, Karin (1999). Die Rolle der Fokuspartikel AUCH im frühen kindlichen Lexikon. In Das Lexikon im Spracherwerb, Jörg Meibauer et al. (eds.), 229-251. Tübingen and Basel: Francke.

Reichenbach, H. (1947). Elements of Symbolic Logic. New York: Free Press.

Rice, Mabel; Noll, Karen R.; and Grimm, Hannelore (1997). An extended optional infinitive stage in German-speaking children with specific language impairment. Language Acquisition 6, 255-295.

-; Wexler, Kenneth; and Cleave, Patrizia L. (1995). Specific language impairment as a period of extended optional infinitive. Journal of Speech and Hearing Research 38, $850-863$.

Riddle, Laura (1992). The attentional capacity of children with specific language impairment. Unpublished doctoral dissertation, Indiana University.

Rizzi, Luigi (1997). The fine structure of the left periphery. In Elements of Grammar. Handbook of Generative Syntax, Liliane Haegeman (ed.), 281-337. Dordrecht: Kluwer.

Roeper, Tom (1996). The role of merger theory and formal features in acquisition. In Generative Perspectives on Language Acquisition, Harald Clahsen (ed.), 415-450. Amsterdam: Benjamins.

Schaner-Wolles, Chris (1994). Intermodular synchronization: on the role of morphology in the normal and impaired acquisition of a verb-second language. In How Tolerant Is 
Universal Grammar? Essays on Language Learnability and Language Variation, Rosemarie Tracy et al. (eds.), 205-224. Tübingen: Niemeyer.

- (2000). Am Anfang ist das Verb, finit markiert ist es erst später. Paper presented at the Jahrestagung of the Deutsche Gesellschaft für Sprachwissenschaft, Marburg.

Schönenberger, Manuela; Pierce, Amy; Wexler Kenneth; and Wijnen, Frank (1996). Account of root infinitives and the interpretation of root infinitives. Geneva Generative Papers 3, 47-71.

Tallal, Paula (1990). Fine-grained discrimination deficits in language-learning impaired children are specific neither to the auditory modality nor to speech perception. Journal of Speech and Hearing Research 33, 616-621.

Tomblin, J. Bruce; and Buckwalter, Paula (1996). Studies of genetics of specific language impairment. In Specific Language Impairments in Children, Ruth Watkins et al. (eds.), 17-34. Baltimore: Paul Brookes.

Tracy, Rosemarie (1991). Sprachliche Strukturentwicklung: Linguistische und kognitionswissenschaftliche Aspekte einer Spracherwerbstheorie. Tübingen: Narr.

-(1994). Raising questions: formal and functional aspects of the acquisition of wh-questions in German. In How Tolerant Is Universal Grammar? Essays on Language Learnability and Language Variation, Rosemarie Tracy et al. (eds.), 1-34. Tübingen: Niemeyer.

von Stutterheim, Christiane (1997). Einige Prinzipien des Textaufbaus. Empirische Untersuchungen zur Produktion mündlicher Texte. Tübingen: Niemeyer.

Weissenborn, Jürgen (1999). The acquisition of V2. Fachgruppe Sprachwissenschaft der Universität Konstanz Arbeitspapier 105, 109-138.

Wettstein, Peter (1983). Logopädischer Sprachverständnistest. Zürich: Heilpädagogisches Seminar.

Wexler, Kenneth (1994). Optional infinitives. In Verb Movement, David Lighfoot et al. (eds.), 305-350. Cambridge: Cambridge University Press.

Wimmer, Heinz; Gruber, Silvia; and Perner, Josef (1984). Young children's conception of lying. Lexical realism - moral subjectivism. Journal of Experimental Child Psychology 37, 1-30.

Wijnen, Frank (1997). Temporal reference and eventivity in root infinitivals. In The Interpretation of Root Infinitives and Bare Nouns in Child Language, Janet Schaeffer (ed.), 1-25. MIT Occasional Papers in Linguistics 12. Cambridge, MA: MIT.

Wode, Hennig (1977). Four stages in the development of L1 negation. Journal of Child Language 4, 87-102. 